\title{
The substitutive relation between voluntary disclosure and corporate governance in their effects on firm performance
}

\author{
Luminita Enache ${ }^{1}$ \\ Khaled Hussainey ${ }^{2}$
}

\begin{abstract}
Prior literature shows that financial disclosures and corporate governance both impact firm performance. This paper documents an important topic that has been overlooked in the prior literature, their joint effect, because the two mechanisms could be independent, substitutive, or complementary in their impact on firm performance. We find a substitutive relation based on data from 2005-2013 for a sample of US biotech firms, but only for firms with products in advanced stages of development, because their disclosures are trustworthy about the firms' future performance. We do not find such effect for firms with early-stage products, that would take years to convert to profits, and whose product-related disclosures are speculative at best. This paper shows that informative and reliable voluntary disclosures have similar value-increasing effect as corporate governance and that the marginal effect of trustworthy disclosures is decreasing in governance. To the extent that the two mechanisms are costly, firms can partly substitute one for the other.
\end{abstract}

Keywords Biotechnology firms, Corporate governance, Voluntary disclosures, Proprietary costs, Firm performance, Complementary or substitutive relationship

JEL classification M40, M41, G14, G32, G34

Acknowledgments: We thank the editor (Cheng-Few Lee), two anonymous reviewers, Lynn Li, Eddie Riedl, Raffaella Santolini, Anup Srivastava, and Hussein Warsame for helpful feedback.

\footnotetext{
${ }^{1}$ Corresponding author: Luminita Enache, Haskayne School of Business, University of Calgary, luminita.enache@ucalgary.ca, Telephone: +1 5874389015.

${ }^{2}$ Khaled Hussainey, Portsmouth Business School, Faculty of Business and Law, University of Portsmouth, PO1 3DE United Kingdom, khaled.hussainey@port.ac.uk, Telephone: +44 2392844715.
} 


\section{Introduction}

Managers often convey their private information to investors via voluntary disclosures. Hence capital market participants benefit when a firm provides transparent and adequate information to assess the firm's future performance. Previous theoretical and empirical literature shows that voluntary disclosures reduce cost of capital (Barry and Brown 1985; Botosan 1997; Sengupta 1998; Easley and O’Hara 2004; Hughes, Liu and Liu 2007; Lambert, Leuz and Verrecchia 2007), improve firm performance and stock liquidity (Diamond and Verrecchia 1991; Kim and Verrecchia 1994; Healy, Palepu and Hutton 1999), and increase information intermediation (Lang and Lundholm 1993; Francis, Huang, Rajgopal, and Zang 2008).

Although there are significant capital market benefits associated with greater transparency, voluntary disclosures are not costless. Voluntary disclosures could reveal information that the firm would otherwise not reveal to competitors, potential entrants, regulators, customers, and suppliers. Any details about R\&D activities, such as products under development, could increase proprietary costs because the rivals might capitalize on that information to more effectively compete with the disclosing firm (Verrecchia 1983; 2001; Dye 1985, 2001; Darrough and Stoughton 1990; Wagenhofer 1990). Hence, managers must trade benefits from reduced information asymmetry against the costs of reducing competitive advantage (Wagenhofer 1990; Hayes and Lundholm 1996). That is, managers must selectively provide forward-looking, business-specific disclosures on R\&D projects, only when their benefits exceed costs (Jones 2007; Merkley 2014).

While firm disclosures can improve investors' decisions, they do not equally benefit all investors. Kalay (2015) argues that disclosures benefit different classes on investors differently depending on their levels of sophistication. Investors with strategic informational advantage might not prefer additional disclosures, because those disclosure would also reach less-informed investors and reduce better-informed investors' trading advantage. On the other hand, investors with no informational advantage, such as common investors, would prefer enhanced disclosures to reduce information asymmetry between managers and investors as well as to reduce trading disadvantage vis-a-vis sophisticated investors. So, the demand for disclosures could differ between different classes of investors.

Disclosures are also a mechanism of improving managers' accountability to shareholders. In a world with complete information, the mechanisms of accountability would be of little utility because investors would price protect themselves. Under incomplete contracts and bounded rationality, however, both corporate governance and voluntary disclosure make managers accountable. Voluntary disclosures reduce information asymmetry and diminish the top managers' extraction of private benefits that occurs in opaque information environments. Well-designed corporate governance also reduces managers' opportunistic behaviour, but, in addition, forces managers to disclose 
more information. Therefore, the two mechanisms of corporate governance and voluntary disclosures can have complementary or substitutive relationship in affecting firm performance.

Extensive literature examines the association between corporate disclosures and firm performance. On one hand, some studies conclude that disclosure improves firm performance (e.g., Plumlee, Brown, Hayes and Marshall 2015; Elzahar, Hussainey, Mazzi and Tsalavoutas 2015). On the other hand, other studies find no association between disclosure and performance (e.g., Hassan, Romilly, Giorgioni and Power 2009; Hassanien and Hussainey 2015). Prior research also provides evidence that better corporate governance improves voluntary disclosures and makes those disclosure more informative (Wang and Hussainey 2013). In this paper, we aim to address an important unanswered question: whether product-related voluntary disclosures affect firm performance and, if so, whether corporate governance enhances or moderates the impact of disclosures on corporate performance (Beekes, Brown, Zhan and Zhang 2016). We respond to call by Christensen (2016) who suggests that future research should examine the interaction between corporate governance and voluntary disclosures in impact on firm performance.

To improve our identification strategy, we examine our research question in a single industry context, the biotechnology sector. The biotech sector provides an appropriate setting for investigating disclosures because incurs large R\&D investments with uncertain payoffs and has large amount of unreported intangible assets, high information asymmetries between managers and investors, and high proprietary costs associated with disclosures about products under development (Guo, Lev and Zhou 2004; Dedman, Lin, Prakash, and Chang 2008; Hussainey and Walker 2009). Biotech companies may increase their levels of voluntary disclosure to reduce information asymmetry and signal their good performance. Furthermore, better corporate governance may force companies to reveal more information to reduce information asymmetries with investors. In that case, corporate governance would have complementary relation with voluntary disclosures in affecting firm performance. On the other hand, because of the high levels of proprietary costs, resulting from disclosing sensitive information that potentially damages the firm's competitive advantages, better-governed biotech companies might keep their voluntary disclosures at low levels. In that case, better corporate governance, instead of large voluntary disclosure, might have greater impact on corporate performance, and the effect of two mechanisms would be substitutive.

We measure firm performance by Tobin's Q consistent with previous literature (e.g., Setia-Atmaja et al. 2009; Zhao and Murrell 2016). We measure the quality of corporate governance using the principal component analysis of eight different governance measures: the proportion of independent directors on the board, board size, CEO duality, board busyness (directors sitting on more than four boards), percentage of women directors, percentage of insider ownership, the frequency of board meetings and percentage of holdings by the top five owners in the company. We retain components with eigenvalues greater than one. We measure corporate disclosures using a unique 
set of hand-collected data from biotechnology firms, following Guo et al. (2004). We construct a disclosure index, based on product specifications, target disease, clinical trials, future development plans, and market information. We employ a battery of control variables in our multivariate tests that could affect firm profitability as well as corporate governance and disclosures, such as firm size and age, leverage, loss, institutional holdings, and accounting accruals.

When examined independently, we find that both disclosure and governance mechanisms positively impact current and future firm performance, up to two years ahead. More important, when considered together, the productrelated disclosure and corporate governance have a substitutive effect on firm performance. This finding provides preliminary evidence of reduced marginal benefits of disclosures in presence of good governance.

We then divide disclosures into two types: those related to early stage products (preclinical) and those related to more advanced stage products (clinical). All else held equal, information on early stage products is highly confidential and can impose large competitive disadvantages when disclosed. Nevertheless, the prospects of these early stage products are highly uncertain, because they can fail at any stage of their development process. Prior studies show that the probability of a chemical compound making it through from discovery (preclinical phases) to final commercialization (market launch) is one in 5,000 (Healy et al. 2002). Hence, any information about preclinical products is unlikely to change investors' assessments of future profitability. In contrast, information on advancedstage products would not only convey promising, positive news about the firm, it would also impose lesser proprietary costs of information, because even if competitors become aware of these products, it would take them long lead times to create competitive products.

We find an insignificant association between preclinical disclosures and firm performance, consistent with the idea that investors have lesser confidence in disclosures on early-stage products. We also find no evidence of substitutive or complementary relationship between preclinical disclosures and corporate governance on firm performance. In contrast, we find a positive association between clinical disclosures and firm performance. More important, we find a strong substitutive relation between corporate governance and clinical disclosures. These results are consistent with the idea that better governance has a similar effect as that of disclosures in impacting firm performance. More important, this substitutive effect holds only for disclosures that are reliable and are better predictors of forthcoming profitability, not for disclosures that enhance uncertainty about future profits.

In sum, this paper contributes to disclosure/governance and firm performance literature by being the firstto the best of our knowledge - to examine the joint effect of disclosure and governance on firm performance (Beyer, Cohen, Lys and Walther 2010). We also provide the first evidence that the impact of disclosure on firm performance depends on the reliability of disclosures. That is, informative and reliable voluntary disclosures have similar valueincreasing effect as corporate governance, but not those that are speculative or uninformative about future 
performance. To the extent that the two mechanisms of corporate governance and proprietary disclosures are costly, firms with more trustworthy disclosures can at least partly substitute one for the other.

The paper proceeds as follows. Section 2 discusses the theoretical framework, reviews prior literature and develops our research hypotheses. Section 3 describes the methodology and the data. Section 4 presents our findings. Section 5 presents our robustness tests. Section 6 concludes.

\section{Hypothesis development}

Several theories explain why firms voluntarily disclose information. Hope (2003, p. 220) argues that "disclosure is inherently a complex phenomenon and a single theory can only give a partial explanation." The section, therefore, develops an overarching theoretical framework that helps in explaining the product-related voluntary disclosure practice of US biotech firms and this practice affect the performance of these firms. Following Chen and Roberts (2010), we introduce a theoretical framework that helps us to develop our research hypotheses and in interpreting the findings. We consider disclosure theories as complementary rather than competing. Our multitheoretical framework includes economic incentive theories (agency theory, signalling theory, capital need theory and information cost theory) and system-oriented theories (political cost theory, stakeholder theory and legitimacy theory).

Accounting theory predicts that capital market benefits accrue to firms when they provide transparent and adequate information useful to the investors in predicting firms' future performance. One mechanism to provide this information is through voluntary disclosures. Firms use disclosure as a mechanism to reduce information asymmetries between managers and investors, to reduce the firms' costs of capital, to increase the stock prices and ultimately increase shareholders' wealth.

However, disclosures are not costless. Signalling theory, originally proposed by Akerlof (1970) and developed by Spence (1973), suggests that companies are motivated to disclose more information to signal their good performance and to avoid any adverse interpretation by stock market participants. Capital need theory suggests that firms will increase the extent of their disclosure information when they need to raise their external finances to reduce their cost of capital (Firth, 1980). Therefore, we expect that companies will provide extensive product-related voluntary disclosure to attract more potential investors and raise their external finances. Information cost theory suggests that companies will provide more information if they potentially gain some economic benefits (Cooke 1992). Therefore, we believe that companies will disclose product-related voluntary disclosure information if the benefits from disclosing information outweigh its costs. These theories suggest that high levels of disclosure lead to desirable economic consequences. Therefore, we expect that such increase in disclosure will have a positive impact on corporate performance. 
The above-mentioned theories, however, emphasise economic and finance perspectives, neglect cognitive, social, and other factors (Elbannan and McKinley 2006). They consider only the relationship between managers and owners and ignore other stakeholders. It is, therefore, important to consider other theories that complement the economic incentive theories.

Deegan and Unerman (2006) classify political economy theory, stakeholder theory, legitimacy theory and institutional theory as system-oriented theories because of the fact that companies are considered part of a social system that interacts with society. Based on political cost theory, Watts and Zimmerman (1990) argue that politically sensitive companies are subject to high political costs and, therefore, are willing to disclose more information to reduce these costs. In our paper, we consider large and profitable firms as politically sensitive and that these firms are likely to be more transparent through more product-related voluntary disclosure to reduce the political cost. Consequently, we expect a higher performance for firms with higher levels of disclosure.

Based on stakeholder theory, companies should treat all stakeholders fairly (O’Dwyer, 2002). However, stakeholders may be treated differently by a firm depending on the power they have (Smith, Adhikari, and Tondkar 2005). In addition, different stakeholders could have differential demand for information (Kalay 2015). This might explain the motives for companies to voluntarily disclose product-related information to satisfy certain stakeholders. Legitimacy theory suggests that companies might have incentives to increase disclosure to meet the perceptions of societies. Firms will have incentives to increase the extent of product-related information to maintain legitimacy status. Institutional theory is concerned with both the interaction of firms with their institutional environment and the impact of the social expectation of the firms. We argue that firms might disclose high level of product-related information in their annual reports to meet the expectation in their institutions.

The above-mentioned theories suggest that demand for corporate disclosure arises from information asymmetry and agency conflicts between insiders (managers) and outsiders (stakeholders). Therefore, managers might increase the levels of disclosure to reduce information asymmetry and agency costs. Considering the fact that financial statement are losing their relevance and, hence, the traditional accounting model no longer satisfies users' needs (Lev, 1989), we expect that managers will disclose more non-financial information. In our paper, we argue that managers of biotechnology firms are more likely to voluntarily disclose more information about their products to complement the information reported in their financial statements. A rich information environment and low information asymmetry could lead to desirable economic consequences. One of these is to improve the firm performance.

\subsection{Disclosure and Firm Performance}

Accounting information plays a role in valuation because it enables capital providers to evaluate potential return on investment opportunities (Beyer et al. 2010). It also plays a stewardship role as it allows capital providers to 
effectively manage and utilize their invested capital in a certain company. Furthermore, corporate disclosure corrects firm mis-valuation and increases the liquidity of a firm's stock (Healy et al. 1999). Athanasakou and Hussainey (2014) show that voluntary disclosure improves the credibility to financial statements and enhances the perceptions of the market's participants of future corporate performance.

Sheu, Chung, and Liu (2010) argue that disclosure should correct any firm misvaluation by reducing information asymmetry among insiders and outsiders, hence, increases firm performance. Corporate performance is increasing in disclosure through either reduced cost of capital, increased cash flow to shareholders or both. In addition, increasing disclosure sends signals to the market that a company's net present value is expected to increase and hence its performance (Gordon, Loeb and Sohail 2010, Zhang and Ding, 2006). Van Buskirk (2012) find that greater disclosure reduces information asymmetry among investors. Empirical research shows that increased disclosure reduces estimation risk in two ways: first, securities with more information are less risky because of lower uncertainty surrounding the exact parameters of their return distribution (e.g., Clarkson, Guedes, and Thompson 1996; Easley and O'Hara 2004); and, second, the covariance of a firm's cash flow with the cash flow of other firms decreases as disclosures increases (e.g., Hughes, Liu and Liu 2007; Lambert et al. 2007). Thus, enhanced disclosure directly reduces the estimation risk that leads to an indirect reduction in the firm's cost of capital. This is also useful in examining the link between disclosure and firm performance. In addition to the direct effects on the covariance of a firm's cash flow, corporate disclosures have the potential to change the firm performance by affecting managers' decisions and, hence, altering the distribution of future cash flows (Lambert et al. 2007). Thus, there might be indirect effects on firm performance through cash flow expectations formed based on enhanced disclosure.

The empirical literature examining the link between corporate disclosure and firm performance offers mixed results. On one hand, several studies find a positive association between these two variables (e.g., Waddock and Graves 1997; Baek, Kang and Park 2004; Chi 2009; Cheung, Jiang and Tan 2010; Sheu et al. 2010; Jiao 2011; Elzahar et al. 2015; Plumlee et al.. 2015). In a recent study, Zhao and Murrell (2016) provide evidence that the positive governance-disclosure relation of Waddock and Graves (1997) is not generalizable to different sample that include more firms over a longer time period. They, however, did not explain the reasons for these mixed results.

On the other hand, Hassan et al. (2009) and Hassanien and Hussainey (2015) find no significant association between firm performance and voluntary disclosure, while a negative and significant relationship exists with mandatory disclosure when the relation of their relationship with market value is tested simultaneously. Hassanien and Hussainey (2015) also find that change in voluntary disclosure has no effect on the value of well-performing firms, while it negatively affects poorly performing firms. 
Several studies hypothesise and find that voluntary disclosure affects future firm performance. These include Clarkson, Kao and Richardson (1994), Bryan (1997) and Clarkson, Kao and Richardson (1999). Related studies find that voluntary disclosure improves investors' ability to anticipate future earnings (e.g. Hussainey, Schleicher and Walker 2003). This suggests that voluntary disclosure contains value relevant information.

Zahller, Arnold and Roberts (2015) provide recent evidence investors perceive companies' legitimacy to be higher with high level of disclosure. This implies that high-quality voluntary disclosure helps protecting corporate financial market performance following an exogenous shock through the disclosure's effect on perceived legitimacy (Zahller et al., 2015). Therefore, we expect that product-related voluntary disclosure might lead to a positive impact on firm performance.

Based on the above arguments, we hypothesise that:

H1: Product-related disclosure is positively associated with current and future firm performance.

\subsection{Governance and Firm Performance}

The governance-performance literature shows that corporate governance affects firm performance (e.g. Cheung, Connelly, Jiang and Limpaphayom 2011). It shows that high-quality governance increases a firm's cash flow, which ultimately is reflected in higher firm performance (Bozec, Dia, and Bozec 2010). It is also argued that corporate governance increases returns to shareholders by reducing transaction and agency costs and, hence, it is considered as a success factor for financial markets (Baek et al. 2004), as better-governed firms have higher firm performance (Gompers, Ishii and Metrick 2003; Klapper and Love 2004; Brown and Caylor 2006; Ammann, Oesch, and Schmid 2011; Braga-Alves and Shastri 2011; Sami, Wang and Zhou 2011; Black, de Carvalho, and Gorga 2012; Ammann, Oesch, and Schmid 2013). La Porta, Lopez-De-Silanes and Vishny (2002) argue that in countries where laws are in favour of investor protection, investors are willing to pay more for a firm's equity. Therefore, investors recognise that with better legal protection, the problem of conflicting investor-management interests will be minimised. This argument presents corporate governance as a kind of investor protection mechanism, which mitigates agency problems and therefore enhances firm performance. Based on these arguments, one should expect a positive association between corporate governance and firm performance. In addition, while Gompers et al. (2003) and Bebchuk, Cohen and Ferrell (2009) find that external governance increases corporate performance, Cremers and Nair (2005) find that both external and internal governance increase corporate performance.

Despite the above, other studies offer contrasting evidence on the association between corporate governance and firm performance (Baek et al. 2004). Some studies find no association between the two variables (Klein, Shapiro and Young 2005). Bozec et al. (2010:685) conclude that, "overall, prior studies fail to find convincing evidence that corporate governance affects firm performance or value". In their review article, Bozec and Bozec (2012) note, 
however, that the relation between governance and performance is positive in Europe and emerging economies, whereas researchers using American and Canadian contexts found mixed evidence on the governance-performance relation.

We expect that good governance should improve firm performance for biotechnology firms, as high-quality governance reduces managers-shareholders' conflicts (Fama and Jensen 1983) and, hence, reduces agency costs and information asymmetry. Consequently, this might lead to an increase in firm performance. Based on the above arguments, we hypothesise that:

H2: Corporate governance is positively associated with current and future firm performance.

\subsection{The Joint Effect of Disclosure and Governance and Firm performance}

The above hypotheses suggest that disclosure and governance separately affect firm performance. To the best of our knowledge, none of the prior research examines the joint effect of disclosure and governance on performance. Disclosure is a core attribute of the corporate governance (OCED 1999) and is regarded as an external factor in the quality of corporate governance system (Chi, 2009). Beekes and Brown (2006) find that firms with high quality governance system have disclosures that are more informative. Beekes et al. (2016), who provide evidence those firms with better corporate governance, substitute the governance process for greater disclosure.

The joint effect of disclosure and governance of firm performance has been only indirectly investigated. For example, Lang and Lundholm (1993) find that the disclosure of governance practice reduces information asymmetry and help investors to effectively monitor management decisions and corporate performance. In addition, Wang and Hussainey (2013) find that disclosure of well-governed firms improves investors' ability to predict future earnings. In our paper, we directly examine the joint impact of disclosure and governance on firm performance.

Following Hussainey and Walker (2009), we propose four different scenarios. First, product related voluntary disclosure and governance are different ways of conveying the same information. Thus, the impact of each variable on firm performance is exactly similar to the joint impact of both variables on firm performance.

H3: The joint effect of product-related voluntary disclosure and governance on firm performance is similar to the impact of each individual variable on current and future firm performance.

Second, product-related voluntary disclosure and governance provide ('additive') unrelated information. Thus, the joint effect of both variables on firm performance should be insignificant.

H4: The joint effect of product-related disclosure and governance on current and future firm performance is additive.

Third, product-related voluntary disclosure and governance provide related information that is 'reinforcing' or 'multiplicative'. In this case, the joint impact of product-related disclosure and governance should be higher than the impact of each variable on firm performance. We refer to this as a complementary effect hypothesis. 
H5: Product-related disclosure and governance are complementary in their impact on current and future firm performance.

Product-related disclosures are costly, on one hand, but reduce the information asymmetry and the associated agency costs, on the other hand. Effective governance and board oversight reduces the agency costs, thereby reduce the need for costly disclosures (Rediker and Seth 1995; Satta et al. 2014). Hence, we now describe that product-related disclosures, corporate governance are strategic substitutes, and that the marginal benefit of disclosures decreases in corporate governance. This idea is consistent with Bulow et al (1985).

H6: Product-related disclosure and governance are substitutes in their impact on current and future firm performance.

\section{Methodology and data}

In this section, we describe the selection of sample firms from the biotechnology sector and the measurement of key variables.

\subsection{Sample selection}

Our sample contains a random sample of the about $10 \%$ active biotechnology firms listed on the US stock exchanges from 2005 to 2013. We restrict our sample to firms that have products under development (other than products involving gene therapy, medical devices, and research services). We retain firms that discontinued drug development for a few years due to the failure of clinical trials (for example, Prana Biotech and PDL Biopharma), provided they had product development during the other years. In these cases, we retain only the firm-year observations in which they conduct development activities. This results in a varying sample size across the study period, consisting of 647 firm-years observations, as described in Table 1.

The biotech industry is particularly interesting from a disclosure point of view: 'the unusually fast innovation pace in the biotech sector and the low barriers to entry enhance competition and ... create large information asymmetries between managers and investors, which increase the benefits of disclosure' (Guo et al., 2004, p. 320). Indeed, biotech companies can experience negative financial performance for a long period; therefore, their ability to attract capital is strictly linked with the ability to build and deploy intangible capital, such as products under development. The products-related information is therefore particularly crucial to our sample of biotech companies because most of them have negligible earnings, low revenues and few physical assets. Our sample of biotechnology firms invest large amounts on $R \& D$ and have product-development cycles running into decades (it can take 10-12 years for a product to reach Food and Drug Administration (FDA) approval and consequently to generate revenues. Therefore, many firms report losses or have negative book values. This is precisely the strength of our study: 
disclosures assume paramount importance because financial statements fail to present an accurate picture of firm's operating performance.

\subsection{Measurement of variables}

The dependent variable, Tobin's Q, is built using COMPUSTAT data, while the independent variables (the various disclosure indexes - total disclosure, preclinical and technical disclosure index and board governance variables- Comp1, Comp2 and Comp3, as described below) are hand-collected from the 10-K form and from the DEF 14A Proxy Statement, respectively. The control variables are constructed using COMPUSTAT data.

\subsubsection{Dependent variable. Why use Tobin's $Q$ ?}

Tobin's Q measures firm performance. Tobin's Q is a widely applied measure within the corporate governance literature that serves as a proxy for a firm's ability to generate shareholder wealth. The denominator in Tobin's Q serves as a proxy for the replacement value of the firm's current assets. If the ratio is less than 1 , it is cheaper to buy capacity in the financial markets than in the real asset markets. If, on the other hand, a firm's Tobin's

Q exceeds 1, this may reflect the presence of strong comparative advantages or growth opportunities (See Himmelberg, Hubbard and Darius 1999) for a careful econometric analysis of managerial ownership and performance relying on Tobin's Q.) One may use other performance measures, e.g., accounting-based measures such as return on equity and return on assets, but these measures are very sensitive to management's choice of asset valuation principles. Other studies use the decomposition of Tobin's Q into three components: price-to-operating earnings, financial leverage, and operating profitability as a measure of firm performance (Fang, Noe, and Tice 2009). Nevertheless, Tobin's Q decomposition is valid only if the three components, price-to-operating earnings, financial leverage, and operating profitability, are in the same direction as Tobin's Q. If any of these three variables is negative, then the sense of directionality is lost. Our biotech sample is not suitable to using the Tobin's Q decomposition as many firms report losses or have negative book values. Eliminating loss or negative book value firms from our sample leads to severe truncation of our sample, more than $60 \%$ observations are lost.

Another possibility is to use risk-adjusted stock returns such as "Jensen's alfa". The dilemma with all riskadjusted performance measures is to find an unbiased proxy for the risk. Unfortunately, this is not the case, as is evident from the existence of a range of risk-adjusted performance measures using different risk measures, e.g., the beta value of the portfolio, three-, four-, or five-factor models, or the portfolio standard deviation. Consequently, the vast majority of studies in corporate governance relies on Tobin's Q. Thus, we use Tobin's Q as our dependent variable to proxy for current firm performance. Following Zhao and Murrell (2016) we use future Tobin's Q as a proxy for future firm performance. 
Baseline Model:

Tobin's $Q_{t+1}=\alpha+\beta_{1}$ discl $_{t}+\beta_{2}$ governance $_{t}+\beta_{3}$ discl $^{*}$ governance $_{t}+\beta_{4}$ total $_{\text {prod }}+\beta_{5}$ leverage $_{t}+\beta_{6}$ firmage $_{t}$

$\beta_{7} \operatorname{loss}_{t}+\beta_{8} \operatorname{lnat}_{t}+\beta_{9} a c c_{t}+\varepsilon$

Where Tobin's Q is the market value of equity plus the book value of total debt divided by the book value of total assets (Setia-Atmaja et al. 2009). The independent variables are defined in Appendix B.

In our main analyses, we include firm fixed effects by demeaning observations by firm to control for the impacts of time-invariant firm characteristics on firm performance.

\subsubsection{Product-development-related information (product disclosure index)}

We employ a unique sample of hand-collected data. Our measure of proprietary cost is based on the disclosure index of Guo et al. (2004). Following their methodology, we construct Product Disclosure for each biotechnology product by hand-collecting relevant information from business section (Part I) of the 10-K. Specifically, the disclosure index is derived from the following five categories: product specifications, target disease, clinical trials, future development plans, and market information. Product Specification captures information on the properties of the product under development. Target Disease captures information on the intended use of the product, which is the type of diseases. Clinical Trials captures information on the success of the clinical trials process, number of patients, method used to test the molecule, results for the various trials. Future Development Plan captures the future product development plans. Market Information captures the products or disease market potential. Each category is assigned a score according to the disclosed information. The maximum score which a product under development disclosure could earn for all the five categories (previously specified) is 30 if the product is on a clinical phase of development or beyond (phase I, II, III or FDA review); and 22 if the product under development is in screening, IND or preclinical phase, according to the Food and Drug Administration (FDA) classification on the various phase of development of biotech products. We hand collect the information for a total number of 5,027 products under development in various stages of development.

Appendix A specifies the components of the disclosure index with an example of the construction of the product-disclosure score for MAXY-G34, one of the products developed by Maxygen in 2008 fiscal year. For each product, we assign a score to the five categories describe above. ${ }^{3}$ To ensure the comparability of the product scores, we divide the summarized disclosure scores by the maximum attainable score of 30 (for the clinical products) and 22 (for the preclinical products). Thus, the product-level disclosure index is the ratio of the disclosure score to the maximum possible disclosure score, and ranges in value from 0 to 1. To compute a firm-year level Product Disclosure score, we average the disclosure score for all products for a firm in a given year.

\footnotetext{
${ }^{3}$ If a product has not entered the clinical trial stage, this category is omitted.
} 


\subsubsection{Board structure measures}

We consider five board-related variables: board independence measured as the percentage of independent directors on the board (comp1); board size measured as the total number of directors (comp2); and the CEO duality is an indicator variable that has a value of 1 if the CEO is also the chair of the firm and 0 otherwise (Comp3).

To develop our corporate governance indices, we use exploratory principal component analysis (PCA) to identify the underlying dimensions or structure of corporate governance and determine which indicators are associated with each factor. We retain all factors with an eigenvalue greater than the unity. This results in three factors (Compl, Comp 2 and Comp3) that retain almost $90 \%$ of the total variance in the original data. This reduced solution is then rotated using an oblique rotation that allows the retained factors to be correlated in order to enhance the interpretability of the results.

Principal component factor analysis is first applied to all the individual measures of corporate governance characteristics - board independence, board size, CEO duality, percentage of women on board, insiders and institutional investors' ownership concentration - to derive an overall factor score for the Governance variable. Three measures - board independence, board size and CEO duality - are loaded on a single factor with an eigenvalue greater than 1 and capture a significant portion of the variance in these variables.

Yermack (1996) verifies Jensen's (1986) prediction of a negative correlation between firm performance and board size. Here, two primary reasons promoted are the increased problems with communication and coordination as group size increases, and the decreased ability of the board to control management because of the 'free-riding' problem (Eisenberg et al., 1998). Furthermore, it has been argued that independent directors are better monitors of managers because of the increased concern of such directors about their reputation in the directorship market (Fama and Jensen, 1983). The board is presumed to become less independent as the number of inside directors increases proportionately. A less independent board is more likely to be characterised by a misalignment of interests between the firms' owners and managers and thereby represents a weaker corporate governance structure. We use board independence, board size, CEO duality and institutional ownership as main variables for corporate governance. We hand-collected these data from the Definitive Proxy Statements (DEF 14A).

\subsubsection{Control variables}

The analysis includes a number of control variables, such as firm size, portfolio of products under development in a given year, leverage, firm age and accruals.

Firms that experience high growth should also expect to have higher Tobin's Q. In the corporate governance literature, concentrated ownership has been proposed as a mechanism to reduce agency costs due to separation and 
control (see, e.g., Shleifer and Vishny 1997). This is why cumulated ownership of shareholders with more than 5 percent is included as a control variable. Firm size is also included as a control variable, as it seems plausible that agency costs are more substantial in larger firms due to the free rider problems associated with these firms

Several studies (Ho and Wong 2001; Chau and Gray 2002) examined the proportion of shares owned by directors and dominant shareholders. They argued that as the proportion of the firm owned by outsiders increases, more information is required to be disclosed to satisfy the information needs of outsiders. We include the ownership held by insiders and top five owners as part of the principal component analysis.

Several studies use firm profitability to predict voluntary disclosure (Lang and Lundholm 1993; Meek, Roberts and Gray 1995; Ho and Wong 2001; Camfferman and Cooke 2002; Hassanein, Zalata and Hussainey 2018; Guo, Chan and Xue 2016). Companies that are performing well are more likely to voluntarily disclose information.

Leverage (Leverage) is the ratio of long-term debt to owners' equity. This measure is used in a number of studies (Chow and Wong-Boren 1987; Meek et al. 1995; Raffournier 1995; Wallace and Naser 1995; Ho and Wong 2001; Camfferman and Cooke 2002; Chau and Gray 2002; Ferguson, Lam and Lee 2002). A positive relationship is expected, as firms with more debt are likely to disclose more information to minimize legal risk. We control for a firm's listing age to control for its stage in life cycle (Lundholm, 2003; Bukh, Nielsen, Gormsen and Mouritsen 2005; Graham, Harvey and Rajgopal 2005). A majority of biotechnology firms incur losses and their consequent needs for external funds can affect their disclosures. We ensure that the disclosure effects we observe are not an artefact of earnings manipulations. We control for accruals because the quality of earnings could also have complimentary and substitutive relation with disclosures (Kim and Verrecchia 1994). Earnings quality and earnings management are proxied by accruals, as is common in the literature (Richardson, Teoh and Wysocki 2004). We find an insignificant relation or positive relation between accruals and firm performance, consistent with the mixed evidence in the literature (Core, Guay, and Verdi 2008).

We control for number of products for two reasons: portfolio diversification and the resources committed to research and development that affects current profitability. Firms diversify their product portfolios to reduce risk. A firm that receives bad news on one project can transfer resources to other products; one with fewer products lacks this possibility. In other words, a firm's number of products both represents and affects its ability to diversify. Guo et al. (2004) use number of products being developed by a firm as to capture product diversification. Higher number of products indicates greater investment in the research and development, which because of the current accounting rules, negatively affects the current reported corporate performance. We, therefore, predict a negative relationship between number of products and profitability. 
Firm size (FirmSize) is the log of total assets. This measure is used in a number of voluntary disclosure studies (see Cooke 1991; Hossain, Perera and Rahman. 1995; Ho and Wong 2001; Camfferman and Cooke 2002; Ferguson et al. 2002; Gul and Leung 2004). There are a number of arguments for larger firms disclosing more information. Large firms are expected to voluntarily disclose more information than smaller firms to reduce the information asymmetry problem that emerges as entities get bigger (Jensen and Meckling 1976, p. 326). Furthermore, Watts and Zimmerman (1978) argue that large firms are more sensitive to political costs and will disclose more information to allay public criticism. Appendix B shows variables definitions and measurement.

\section{$4 \quad$ Results}

\subsection{Univariate analysis}

Table 1 presents the descriptive statistics. The mean value of Tobin's Q is 3.458. On average, firms disclose around 30 percent about their products under development. This is not surprising given the proprietary nature of the information embedded in the biotech industry. Even less (0.126) is the disclosure about products in early stages of development (e.g., Discl_Precl). The firms have, on average, about seven products (TotalProduct) in the pipeline in a given year. The biotech industry comprises young firms and less-profitable firms. In fact, the mean of years since inception (FirmAge) is 10 years with a maximum of 30 years; on average, about 22 percent of the firms are incurring losses (Loss).

Table 2 reports the correlations between Tobin's Q, disclosure, governance and control variables. Firm performance $(T Q)$ is positively correlated with the overall disclosure index (Discl_Index), with the preclinical disclosure (Precl_Discl) and technical disclosure (Tech_Discl). Firm performance with corporate governance, however, is not clear. While Comp3 is positively associated, Compl has a negative association. Firm age (FirmAge) is positively and significantly associated with firm performance $(T Q)$.

\subsection{Multivariate analysis}

Results of the multivariate analysis are presented in Tables 3, 4 and 5. To control for time-specific effects, we include dummy variables that equals one for each of the years 2005-2013 and zero otherwise. We estimate Eq. (1) using a fixed effects regression with standard errors clustered at the firm level. The fixed effects model has the advantage of controlling for the unobservable firm characteristics that are constant over time and correlated with the independent variables (Greene, 2000). We have an unbalanced panel data.

In Table 3, we present the results of the effect of total product-disclosure index (Discl_Index) and corporate governance (Comp1, Comp2 and Comp3) on firm performance. We measure, corporate governance using components with an eigenvalue greater than one resulting from the principal component analysis. Column (1) presents the results of the regression for the effect of overall disclosure (Discl_Index) and Compl on firm performance proxy by Tobin's 
Q $(T Q)$. We find that firms that disclose more tend to have a higher performance up to two periods ahead. Indeed, the coefficient on Discl_Index is positive and significant in all three columns (1-3) of Table 3. In year ( $\mathrm{t}+3)$, the results are insignificant, many other factors could affect the three-years-ahead firm performance (e.g., discontinuing certain products, failure in the efficiency of the targeted disease, etc.).

The coefficients on the interaction term, Discl_Index $\times P 2$, in Column 1-3 suggest a substitutive effect between the extent of voluntary disclosure provided by the biotech firms and the governance mechanisms (Comp2). This means that companies prefer either to engage in good reporting or to signal the good quality of the firm by employing better monitoring devices to enhance firm performance.

The sample size differs in the three tables (Table 3-5) based on the different definitions or missing dependent and independent variables. For example, we have 342 firm-years observations for Comp1, Comp2 and Comp3 in Table 3, 4 and 5. The number of observations for total disclosure index, preclinical disclosure index and technical disclosure index, however, varies across the sample in Table 3-5. Therefore, the test observation varies when disclosure variables are interacted with Comp1, Сomp2, and Comp3. The number of observations with future data, for firms with Tobin's $Q$ in years $(t+1),(t+2),(t+3)$, changes as well. For example, Column 1 of Table 3 has 307 observations for $T Q(\mathrm{t})$, but only 298 observations for $T Q(\mathrm{t}+1)$ in Column 2 . Another possibility was to conduct all tests with common set observations that have no missing variables for any test. We have not followed that design because it will drastically reduce our already small sample, which is based on hand-collected data from biotechnology firms.

Further, we analyse whether early-stage product disclosures (Discl_Precl) and corporate governance (Comp1,Comp2, Comp3) improve firm performance $(T Q)$. Table 4 reports the results. We do not find evidence that investors appreciate the disclosure provided by the biotech firms for their early-stage products (e.g., products in Investigational New Drug Application (IND), screening, development and in the preclinical phases according to the FDA drug classification). These results are consistent with Dedman et al.'s (2008) study, which shows that investors start having confidence in the firms' products when they reach Phase II of development.

When we look at the overall information environment and how that affects the firm performance, we do not find any supporting evidence. Note that the interaction between firm disclosure and the second Comp (Comp $2=$ board size) of corporate governance is insignificant with preclinical disclosures (Table 4) but significant with more advanced stage disclosures. The latter type of disclosures is more informative and reliable, because they are closer to product launch and profitability, than are disclosures on products that are in early experimental stage and have a long way to go. Therefore, the later type of disclosures that are better predictive of forthcoming profitability than are formal disclosures that merely convey highly uncertain prospects. Our results show that disclosures and corporate governance 
have a substitutive relationship, but only for disclosures related to advanced-stage products and not for products that are literally shot-in-dark. These results are consistent with the idea that better governance has similar effect as enhanced disclosures, but only for disclosures that have significant information-asymmetry reducing effect.

Finally, in Table 5 we look at the extent of technical product-related disclosure, proxied by Tech_Discl information (e.g., disclosure about product specifications-information about why the product is better than competing/existing products on the market, what the composition of the molecule is, target disease and clinical trials) and corporate governance (Comp1, Comp2, Comp3) affect current and future firm performance proxied by Tobin's Q. The information about the product specification contains strategic and important disclosure about the efficacy, toxicity and composition of the products. Moreover, it also contains critical disclosure about the innovation activities the firms are pursuing. We find a positive and significant ( $\mathrm{p}$-value $<5 \%$ ) effect on the firm performance up to three periods ahead. See the results for Columns 1-3 of Table 5. This means that this information is valuable to investors who appreciate the specificities of the product under development disclosure. In Columns 1-3, we find a positive impact of the second component (Comp2) on the firm performance $(T Q)$. These results support the mixed evidence of the effect of board size on firm performance. The interaction coefficient (Tech_Discl $\times P 2)$ is negative and significant, supporting a substitution effect between technical product-disclosure and governance. Please note that sample size differs in the three tables and across the various columns (Tables 3,4 and 5) because of the different definitions and measurement of dependent and independent variables, particularly such as firm disclosures (total disclosure index, preclinical disclosure index and technical disclosure index), their interactions with the governance variables (Comp1, Comp2 and Comp3) as well as the definition for the future Tobin's $Q(t+1, t+2, t+3)$.

\section{Robustness tests}

We perform a series of robustness tests. First, as a measure of board busyness, we use the percentage of board members who are on more than four boards. Second, we include the percentage of insiders' ownership in the principal component analysis; the results remain qualitatively the same. Third, information asymmetry leads to disclosure clientele, which is turn, affects the firm's choice of corporate governance. We acknowledge this possibility. We partly address this issue by controlling for institutional ownership, which we believe proxies in part for the role of ownership by index funds. Please note that our main dependent variable is firm performance, while our key independent variables are the fixed effects of, and interaction between, corporate governance and disclosures. Thus, whether disclosures affect institutional ownership, and thus, governance or whether governance affects disclosures, the empirical tests remain substantially the same. The results for this robustness test are presented in Tables 6,7 and 8 .

Fourth, we control for the endogeneity problem using lagged independent variables as suggested in González (2015). Note that our dependent variable is also measured in future years, thus, by construction, the independent 
variables are lagged. The use of lagged variable is also in line with Larcker and Rusticus (2010), methods of resolving possible reverse causality problems as well as the existence of a potential simultaneous relationship between the disclosures and firm performance. We also address the likelihood of disclosures affecting governance instead of the other way around. Firms could select their type of disclosures to attract a certain type of investors who implement different corporate governance practices. We conduct an additional test, by using lagged governance variable to reduce the possibility of governance affecting. Tables 9, 10 and 11 reports the results for the lagged TQ-disclosure and governance. The results remain consistent as in the main tables: Tables 3, 4, and 5 .

\section{Conclusions}

We extend prior research on disclosure-performance and governance-performance relationships by examining an important issue: whether firms use disclosure and governance mechanisms as substitutes or complementary mechanisms to signal their performance. We also investigate whether this relationship depends on the informativeness and reliability of disclosures.

We find that corporate voluntary disclosure positively affects both current and future firm performance in years $(t+1)$ and $(t+2)$. We also find that governance mechanisms (Comp2) positively affect both current and future firm performance in years $(t+1)$ and $(t+2)$. When we examine the joint effect of product-related disclosure and governance, we find that disclosure and governance are substitutes in explaining the current and future performance of biotech companies. So, the marginal benefit of corporate governance and disclosures in improving firm performance is decreasing in the presence of each other.

Additional analysis shows that our findings are sensitive to the type of product-related disclosure by biotech companies. When we focus on firms with early-stage product disclosures, we find that neither disclosure nor governance affect firm performance. However, when we focus on firms that disclose technical product-related information, we find that both disclosure and governance affect firm performance and are substitutes. Yet this substitutive relation holds only for disclosures that have significant information-asymmetry reducing effect.

We contribute to a growing literature on disclosure, governance and firm performance by being the first to study the joint impact of governance and disclosure on firm performance. Our findings suggest promising opportunities for future research. While we use a good proxy for product-related disclosure quality, future research could develop a more refined measure of quality that considers the qualitative characteristics of useful information suggested by International Accounting Standard Board, IASB, 2010. In the future, it would be interesting to examine the factors that determine the choice between disclosure and governance as substitute forms for biotech firms. 


\section{REFERENCES}

Ammann, M, Oesch, D, Schmid, M. (2011) Corporate governance and firm value: International evidence, Journal of Empirical Finance 18 (1): 36-55.

Ammann, M, Oesch, D, Schmid, M. (2013) Product market competition, corporate governance, and firm value: Evidence from the EU area, European Financial Management 19 (3): 452-496.

Akerlof, G. A. (1970) The market for "Lemons": Quality uncertainty and the market mechanism. The Quarterly Journal of Economics 84 (3): 488-500.

Athanasakou, V, Hussainey, K. (2014) The perceived credibility of forward-looking performance disclosures. Accounting and Business Research 44 (3): 227-259.

Baek, J, Kang, J, Park, K.S. (2004) Corporate governance and firm value: evidence from the Korean financial crisis. Journal of Financial Economics 71: 265-313.

Barry, C, Brown, S. (1985) Differential information and security market equilibrium. Journal of Financial and Quantitative Analysis 20: 407-422.

Bebchuk, L, Cohen, A, Ferrell, A. (2009) What matters in corporate governance? Review of Financial Studies 22(2): 738-827.

Beekes, W, Brown, P. (2006) Do better-governed Australian firms make more information disclosures? Journal of Business Finance and Accounting 33(3-4): 422-450.

Beekes, W.A, Brown, P.R, Zhan, W, Zhang, Q. (2016) Corporate governance, companies' disclosure practices and market transparency: A cross-country study. Journal of Business Finance and Accounting 43(3-4): $263-297$.

Beyer, A, Cohen, D. A, Lys, T. Z, Walther, B. R. (2010) The financial reporting environment: review of the recent literature, Journal of Accounting and Economics 50: 296-343.

Black, B, de Carvalho, A, Gorga, E. (2012) What matters and for which firms for corporate governance in emerging markets? Evidence from Brazil (and other BRIK countries), Journal of Corporate Finance 18(4): 934-952.

Botosan, C. A. (1997). Disclosure level and the cost of equity capital. The Accounting Review 72 (3): $323-349$.

Bozec, R, Bozec, Y. (2012) The use of governance indexes in the governance-performance relationship literature: International evidence, Canadian Journal of Administrative Sciences 29(1): 79-98.

Bozec, R, Dia, M, Bozec, Y. (2010) Governance performance relationship: A re-examination using technical efficiency measures, British Journal of Management 21(3): 684-700.

Braga-Alves, M. V, Shastri, K. (2011) Corporate governance, valuation, and performance: Evidence from a voluntary market reform in Brazil. Financial Management 40 (1): 139-157.

Brown, D, Caylor, L. (2006) Corporate governance and firm valuation, Journal of Accounting and Public Policy 25 (4): 409-434.

Bryan, S.H. (1997) Incremental information content of required disclosures contained in management discussion and analysis. The Accounting Review 72 (2): 285-301.

Bulow, J., Geanakoplos, J, Klemperer, P. (1985). Multimarket oligopoly: strategic substitutes and strategic complements. Journal of Political Economy 93(3): 488-511.

Bukh, N, Nielsen, C, Gormsen, P, Mouritsen, J. (2005) Disclosure of information on intellectual capital in Danish IPO prospectuses. Accounting, Auditing, and Accountability Journal 18, 713-732.

Camfferman, K, and Cooke, T.E. (2002) An analysis of disclosure in the annual reports in the U.K. and Dutch Companies. Journal of International Accounting Research 1(1): 3-30.

Chau, G. K, Gray, S. J.( 2002). Ownership structure and corporate voluntary disclosure in Hong Kong and Singapore. The International Journal of Accounting 37: 247-265.

Chen, C.J.P, Jaggi, B. (2000) Association between independent nonexecutive directors, family control, and financial disclosures in Hong Kong. Journal of Accounting and Public Policy 19: 285-310.

Chen, J. C, Roberts, R.W. (2010) Toward a more coherent understanding of the organization-society relationship: A theoretical consideration for social and environmental accounting research. Journal of Business Ethics 97: 651665.

Cheung Y.L, Connelly, J.T, Jiang, P, Limpaphayom, P. (2011) Does corporate governance predict future performance? Evidence from Hong Kong”. Financial Management 40 (1): 159-197.

Cheung, Y.L, Jiang, P, Tan, W.Q. (2010) A transparency disclosure index measuring disclosures: Chinese listed companies. Journal of Accounting and Public Policy 29 (3): 259-280.

Chi, L. (2009) Do transparency and disclosure predict firm performance? Evidence from the Taiwan market. Expert Systems with Application 36: 11198-11203.

Chau, G.K, Gray, S.J. (2002). Ownership structure and corporate voluntary disclosure in Hong Kong and Singapore. The International Journal of Accounting 37: 247-265.

Chow, C.W, Wong-Boren, A. (1987) Voluntary financial disclosure by Mexican corporations. The Accounting Review 62: 533-541.

Christensen, D. (2016) Corporate accountability reporting and high-profile misconduct. The Accounting Review 91(2): 377-399.

Clarkson, P. M, Kao, L. J, Richardson, G. D. (1994). The voluntary inclusion of forecasts in MD\&A in annual reports. Contemporary Accounting Research 11: 423-450. 
Clarkson, P, Guedes, J, Thompson, R. (1996) On the diversification, observability and measurement of estimation risk. Journal of Financial and Quantitative Analysis 31 (1): 69-84.

Clarkson, P. M, Kao, J. L, Richardson, G. D. (1999) Evidence that management discussion and analysis (MD\&A) is a part of a firm's overall disclosure package. Contemporary Accounting Research 16(1): 111-134.

Cooke, T.E. (1992) The impact of size, stock market listing and industry type on disclosure in the annual reports of Japanese listed companies, Accounting and Business Research 22 (87): 229-237.

Core, J. E., Guay, W. R, Verdi, R. S. (2008). Is accruals quality a priced risk factor? Journal of Accounting and Economics, 46 (1): 2-22.

Cremers, KJ, Nair, VB. (2005). Governance mechanisms and equity prices. The Journal of Finance 60(6): 2859-2894.

Darrough, M.N, Stoughton, N.M.(1990) Financial disclosure policy in an entry game. Journal of Accounting and Economics 12: 219-243.

Dedman, E, Lin, S, Prakash, A, Chang, C. (2008) Voluntary disclosure and its impact on share prices: evidence from the UK biotechnology sector, Journal of Accounting and Public Policy 27 (3): 195-216.

Deegan, C, Unerman, J. (2006) Financial accounting theory, McGrawHill, New York.

Diamond, D.W, Verrecchia, R.E. (1991) Disclosure, liquidity, and the cost of capital. Journal of Finance 41: 1325-1359.

Dye, R.A. (1985) Disclosure of nonproprietary information. Journal of Accounting Research 23: 123-145.

Dye, R.A. (2001) An evaluation of "essays on disclosure" and the disclosure literature in accounting, Journal of Accounting and Economics 32(1): 181-235.

Easley, D, O’Hara, M. (2004) Information and the cost of capital. Journal of Finance 59: 1553-1583.

Elbannan, M, and McKinley, W. (2006) A theory of the corporate decision to resist FASB standards: An organization theory perspective. Accounting, Organizations and Society 31(7): 601-622.

Elzahar, H, Hussainey, K, Mazzi, F and Tsalavoutas, I. (2015) The Economic consequences of Key Performance Indicators' disclosure quality. The International Review of Financial Analysis 39: 96-112.

Fama, E, Jensen, M. (1983). Separation of ownership and control. Journal of Law and Economics 26: 301-325.

Fang, V. W, Noe, T. H, Tice, S. (2009) Stock Market Liquidity and Firm Value. Journal of Financial Economics, 94, $150-169$.

Ferguson, M.J, Lam, K.C.K, Lee G.M. (2002) Voluntary disclosure by state-owned enterprises listed on the stock exchange of Hong Kong. Journal of International Financial Management and Accounting 13(2): 125-152.

Firth, M. (1980) Raising finance and farm's corporate reporting policies. Abacus 16 (2): 100-115.

Francis, J, Huang, A.H, Rajgopal, S, Zang, A. (2008). CEO reputation and earnings quality. Contemporary Accounting Research 1: 109-147.

Gompers, P, Ishii, J, Metrick, A. (2003) Corporate governance and equity prices. The Quarterly Journal of Economics 118 (1): 107-156.

González, V. (2015) The financial crisis and corporate debt maturity: the role of banking sector. Journal of Corporate Finance 33: 310-328.

Gordon, L.A, Loeb, M.P, Sohail, T. (2010) Market value of voluntary disclosures concerning information security. MIS Quarterly 34 (3): 567-594.

Gul, F. A, Leung, S. (2004) Board leadership, outside directors' expertise, and voluntary corporate disclosures. Journal of Accounting and Public Policy 23: 351-379.

Guo, R, Lev, B, Zhou, N. (2004) Competitive costs of disclosure by biotech IPOs. Journal of Accounting Research 42: 319-355.

Guo Z, Chan K, Xue Y (2016) The impact of corporate culture disclosure on performance: a quantitative approach. Review of Pacific Basin Financial Markets and Policies 19(2):1_29.

Graham, J. R, Harvey, C. R, Rajgopal, S. (2005) The economic implications of corporate financial reporting. Journal of Accounting and Economics 40, 3-73.

Hassan, OAG, Romilly, P, Giorgioni, G, Power, D. (2009) The value relevance of disclosure: evidence from the emerging capital market of Egypt. International Journal of Accounting 44(1): 79-102.

Hassanein, A, Hussainey, K. (2015) Is forward-looking financial disclosure really informative? Evidence from UK narrative statements. International Review of Financial Analysis 41: 52-61.

Hayes, R. M, Lundholm, R. (1996) Segment reporting to the capital market in the presence of a competitor. Journal of Accounting Research 34 (2): 261-279.

Healy, P, Palepu, K, Hutton, A. (1999) Stock performance and intermediation changes surrounding sustained increases in disclosure. Contemporary Accounting Research 16: 485-520.

Healy, P. M, Myers, S. C, Howe, C.D. (2002) R\&D accounting and the trade-off between the relevance and objectivity. Journal of Accounting Research 40 (3): 677-710.

Himmelberg, C.P, Hubbard, R.G, Darius, P. (1999) Understanding the determinants of managerial ownership and the link between ownership and performance. Journal of Financial Economics 53(3): 353-384.

Ho, S. M, Wong, K. S. (2001) A study of the relationship between corporate governance structures and the extent of voluntary disclosure. Journal of Accounting, Auditing, and Taxation 10: 139-156.

Hope, O.( 2003) Firm-level disclosures and the relative roles of culture and legal origin. Journal of International Financial Management \& Accounting 14(3): 218-248. 
Hossain, M, Perera, M. H. B, Rahman, A. R. (1995) Voluntary disclosure in the annual reports of New Zealand companies. Journal of International Financial Management and Accounting 6: 69-87.

Hughes, J. S, Liu, J, Liu, J. (2007) Information asymmetry, diversification, and the cost of capital. The Accounting Review 82: 705-729.

Hussainey, K, Schleicher, T, Walker, M. (2003) Undertaking large-scale disclosure studies when AIMR-FAF ratings are not available: the case of prices leading earnings. Accounting and Business Research 33 (4): $275-294$.

Hussainey, K, Walker, M. (2009) The effects of voluntary disclosure policy and dividend propensity on prices leading earnings. Accounting and Business Research 39(1): 37-55.

Hassanein, A, Zalata, A. and Hussainey, K. (2018) Do forward-looking narratives affect investors' valuation of UK FTSE all-shares non-financial firms? Review of Quantitative Finance and Accounting, forthcoming.

Jensen, M. C. (1986) Agency cost of free cash flow, corporate finance, and takeovers. American Economic Review, 76, 2, 323-329

Jensen, M, Meckling, W. (1976) Theory of the firm: managerial behavior, agency costs, and ownership structure. Journal of Financial Economics 3: 305-360.

Jiao, Y. (2011) Corporate disclosure, market valuation, and firm performance. Financial Management 40(3): 647-676.

Jones, D. A. (2007). Voluntary disclosure in R\&D-intensive industries. Contemporary Accounting Research 24: 489522.

Kalay, A. (2015) Investor sophistication and disclosure clienteles. Review of Accounting Studies 20 (2): 976-1011.

Kim, O, Verrecchia, R. E. (1994) Market liquidity and volume around earnings announcements. Journal of Accounting and Economics 17: 41-67.

Klapper, L, Love, I. (2004) Corporate governance, investor protection, and performance in emerging markets, Journal of Corporate Finance 10 (5): 703-728.

Klein, P, Shapiro, D, Young, J. (2005) Corporate governance, family ownership and firm value: The Canadian evidence, Corporate Governance: An International Review 13 (6): 769-784.

La Porta, R, Lopez-De-Silanes, S. A, Vishny, R. (2002) Investor protection and corporate valuation, Journal of Finance 57 (3): 1147-1170.

Larcker, D. F, Rusticus, T. O. (2010) On the use of instrumental variables in accounting research. Journal of Accounting and Economics 49 (3): 186-205.

Lambert, R.A, Leuz, C, Verrecchia, R.E. (2007) Accounting information, disclosure, and cost of capital. Journal of Accounting Research 45: 385-420.

Lang, M. H, Lundholm, R. J. (1993) Cross-sectional determinants of analysts' ratings of corporate disclosures. Journal of Accounting Research 31: 246-271.

Lundholm, R. (2003). Historical accounting and the endogeneous credibility of current disclosures. Journal of Accounting, Auditing, and Finance 18, 207-229

Meek, G. K, Roberts, C. B, Gray, S. J. (1995). Factors influencing voluntary annual report disclosures by US and UK and continental European multinational corporations, Journal of International Business Studies 26: 555-572.

Merkley, K. J. (2014) Narrative disclosure and earnings performance: evidence from R\&D Disclosures. The Accounting Review 89: 725-757.

McGuire, J.B, Sundgren, A, Schneeweis, T. (2017) Corporate social responsibility and firm financial performance. Academy of Management Journal 31(4). Published Online 30 Nov 2017: https://doi.org/10.5465/256342

OECD (1999) Benchmarking knowledge-based economy. Paris: Organization for Economic Cooperation and Development.

O’Dwyer, B. (2002) Managerial perceptions of corporate social disclosure: An Irish story", Accounting, Auditing \& Accountability Journal 15(3): 406-436.

Plumlee, M, Brown, D, Hayes, R, Marshall, R.S. (2015) Voluntary environmental disclosure quality and firm value: Further evidence. Journal of Accounting and Public Policy 34 (4): 336-361.

Raffournier., B. (1995) The determinants of voluntary financial disclosure by Swiss listed companies. European Accounting Review 4: 261-280.

Rediker, K, Seth, A. (1995) Boards of directors and substitution effects on alternatives governance mechanisms. Strategic Management Journal 16 (2): 85-99.

Richardson, S. A, Teoh, S.H, Wysocki, P.D. (2004) The walk-down to beatable analyst forecasts: the role of equity issuance and insider trading incentives. Contemporary Accounting Review 21(4): 885-924.

Sami, H, Wang, J, Zhou, H. (2011) Corporate governance and operating performance of Chinese listed firms, Journal of International Accounting, Auditing and Taxation 20 (2): 106-114.

Satta, G, Parola, F, Profumo, G, Penco, L. (2014) Corporate governance mechanisms and disclosure in medium-sized listed firms: substitutes or complements? International Journal of Globalisation and Small Business 6 (1): $37-63$.

Sengupta, P. (1998) Corporate disclosure quality and the cost of debt. The Accounting Review 63: 459-474.

Setia-Atmaja, L, Tanewski, G.A, and Skully, M. (2009) The role of dividends, debt and board structurein the governance of family controlled firms. Journal of Business, Finance and Accounting 36 (7-8): 863-898.

Sheu, H. J, Chung, H, Liu, C. L. (2010) Comprehensive disclosure of compensation and firm value: The case of policy reforms in an emerging market. Journal of Business Finance and Accounting 37: 1115-1144.

Shleifer, A, Vishny, R.W. (1997) A survey of corporate governance. Journal of Finance 52(2): 737-783. 
Skinner, D. J. (1994) Why firms voluntarily disclose bad news. Journal of Accounting Research 32: 38-61.

Smith, J.L, Adhikari, A, Tondkar, R.H. (2005) Exploring differences in social disclosure internationally: a stakeholder perspective. Journal of Accounting and Public Policy 24: 123-151.

Spence, M. (1973) Job market signaling. The Quarterly Journal of Economics 87 (3): 355-374.

Verrecchia, R.E. (1983) Discretionary disclosure. Journal of Accounting and Economics 5: 365-380.

Verrecchia, R.E. (2001) Essays on disclosure, Journal of Accounting and Economics, 32, 97-180.

Van Buskirk A (2012) Disclosure frequency and information asymmetry. Review of Quantitative Finance and Accounting 38(4): 411_440.

Waddock, SA, Graves, SB. (1997) The corporate social performance-financial performance link. Strategic Management Journal 18 (4): 303-319.

Wallace, R.S.O, and Naser, K. (1995) Firm-specific determinants of the comprehensiveness of mandatory disclosure in the corporate annual reports of firms listed on the stock exchange of Hong Kong. Journal of Accounting and Public Policy 14(4): 311-368.

Wagenhofer, A, (1990) Voluntary disclosure with a strategic opponent. Journal of Accounting and Economics 12: 341_364.

Wang, M, Hussainey, K. (2013) Voluntary forward-looking statements driven by corporate governance and their value relevance. Journal of Accounting and Public Policy 32 (3): 26-49.

Watts, R.L, Zimmerman, J.L. (1978) Towards a positive theory of the determination of accounting standards. The Accounting Review 53(1): 112-134.

Watts, R. L, Zimmerman, J. L. (1990) Positive accounting theory: A ten year perspective. The Accounting Review 66 (1): 131-156.

Yermack, D. (1996) Higher market valuation of companies with a small board of directors. Journal of Financial Economics 40(2): 185-211.

Zahller, K. A, Arnold, V, Roberts, R. W. (2015) Using CSR disclosure quality to develop social resilience to exogenous shocks: A test of investor perceptions. Behavioral Research in Accounting 27(2): 155-177.

Zhao, X, Murrell, A. (2016) Revisiting the corporate social performance-financial performance link: a replication of Waddock and Graves. Strategic Management Journal 37: 2378-2388.

Zhang L, Ding S (2006) The effect of increased disclosure on cost of capital: Evidence from China. Review of Quantitative Finance and Accounting 27(4):383_401. 


\section{APPENDIX A}

Product disclosure index

The disclosure index is constructed for each biotechnology product by hand-collecting relevant information from annual reports (Business section of Form 10-K). Information is derived for the following five categories: product specifications, target disease, clinical trials, future development plans, and market information. The procedure for assigning scores in each category is tabulated (with a detailed example) in the Appendix A continued.

\section{C.1. Measurement of product disclosure index}

\section{Product specifications}

1. How does the product work? $(3$ points $=$ three sentences; $2=$ two sentences; $1=$ one sentence; $0=$ none $)$

2a. Why is it better than previous products? $(2=$ name mentioned; $1=$ no name mentioned; $0=$ no discussion $)$

b. Why is it better than competing products? $(2=$ name mentioned; $1=$ no name mentioned; $0=$ no discussion $)$

3. What is the chemical/biological structure? $(2=$ chemical compound; $1=$ general discussion; $0=$ not mentioned)

Subtotal $I=$ total scores of $(1+\max (2 a, 2 b)+3)$

\section{Target disease}

1. What kind of diseases does the product treat? $(2=$ disease name mentioned; $1=$ disease name not mentioned; 0 = no discussion)

2. What are other possible uses of the drug? $(2=$ disease name mentioned; $1=$ disease name not mentioned; $0=$ no discussion)

Subtotal II = total scores of $(1+2)$

\section{Clinical trials}

1. Number of patients $(1=$ given; $0=$ absent $)$

2. Patients information (with what diseases) $(1=$ given; $0=$ absent $)$

3. Doses (amounts) used in the clinical trial ( $1=$ given; $0=$ absent $)$

4. Method used in the clinical trial $(1=$ given; $0=$ absent $)$

5. Treatment schedule (duration or frequency) $(1=$ given; $0=$ absent)

6. Trial results $[$ detailed $=$ pro and cons + numbers $(3)$; general $=$ numbers $(2)$; brief $=$ no numbers $(1)$; none $(0)$ ]

Subtotal III = total scores of $(1+2+3+4+5+6)$

\section{Future plans}

1a. Is there any plan to try the product on new diseases? $(2=$ disease name mentioned; $1=$ no name mentioned; 0 $=$ no discussion)

1b. Is there any plan to try the product with other products? $(2=$ name mentioned; $1=$ no name mentioned; $0=$ not mentioned)

2. Future plan for clinical trials

2a. Planned date $(1=$ mentioned; $0=$ not mentioned $)$

2b. Number of patients for the planned trial $(1=$ mentioned; $0=$ not mentioned $)$

2c. Patient information for the planned trial (what disease) $(1=$ mentioned; $0=$ not mentioned)

2d. Duration $(1=$ mentioned; $0=$ not mentioned $)$

2e. Method $(1=$ mentioned; $0=$ not mentioned $)$

3. Possible alliance $(2=$ name mentioned; $1=$ no name mentioned; $0=$ not mentioned $)$

Subtotal $I V=$ total scores of $(\max (1 a, 1 b)+2 a+2 b+2 c+2 d+2 e+3)$

\section{Market information}

1. Number of patients affected by the disease $(1=$ mentioned; $0=$ not mentioned $)$

2. Number of incidents (market size) $(1=$ mentioned; $0=$ not mentioned)

Subtotal $V=$ total scores of scores $(1+2)$

Overall disclosure score $=$ sum of Subtotals I-V

Scaled disclosure score = overall disclosure score divided by 30 for products either in or beyond the clinical trials phase; by 22 for the products that did not reach clinical trials 


\section{APPENDIX A continued}

Product disclosure index

C.2. An example of the measurement of product disclosure index

\section{Company}

Product

Development stage
MAXYGEN

MAXY-G34

Phase II

Score contents

Disclosure index (information is drawn from the

Business section, Part I, of Form 10-K)

I. Product specifications

1. How does the product work? $(3=$ three sentences; 2 = two sentences; $1=$ one sentence; 0 $=$ none)

2a. Why is it better than previous products? $(2=$ name mentioned; $1=$ no name mentioned; $0=$ not mentioned)

2b. Why is it better than competing products? ( 2 $=$ name mentioned; $1=$ no name mentioned; $0=$ not mentioned)

3. What is the chemical structure in addition to its chemical name? $(2=$ name mentioned; $0=$ not mentioned)

Subtotal $I=$ total scores of $(1+\max (2 a, 2 b)+$ 3)

II. Target diseases

1. What kind of diseases does the product treat? ( $2=$ disease name mentioned; $1=$ disease name not mentioned; $0=$ not mentioned)

2. What are the other possible uses? $(2=$ disease name mentioned; 1 = disease name not mentioned; $0=$ not mentioned)

1. Helps the body make blood cells.

2. MAXY-G34 reduces the duration of neutropenia when compared with the currently marketed products (Neulasta and Neupogen).

2. MAXY-G34 protects patients from chemotherapy and radiation therapy-related infections, shortens the duration of hospital stays, and helps keep patients on schedule for their cancer treatments.

0. Not mentioned.

3 , out of a maximum of 7 .

\section{Neutropenia.}

0 . Not mentioned.

Subtotal II = total scores of $(1+2)$ 2 , out of a maximum of 4 .

III. Clinical trials

1. Number of patients $(1=$ mentioned; $0=$ not mentioned)

2. Patients information (with what disease) $(1=$ name mentioned; $0=$ not mentioned)

3. Doses (amounts) used in the clinical trial $(1=$ mentioned; $0=$ not mentioned)

4. Method (via what kind of media) used in the clinical trial $(1=$ mentioned; $0=$ not mentioned $)$

5. Treatment schedule (duration or frequency) (1 $=$ given $; 0=$ absent $)$

6. Results $(3=$ detailed discussion; $2=$ general discussion; 1 = brief discussion; $0=$ no discussion)

Subtotal III $=$ total scores of $(1+2+3+4+5+$ 6)

1. Patients with breast cancer who have failed at least one potentially curative treatment regimen.

1. 5 to $100 \mu \mathrm{g} / \mathrm{kg}$ was given.

1. Subcutaneous injection.

1. Single dose MAXY-G34 therapy being administered per three-week chemotherapy cycle with each patient receiving six cycles of docetaxel.

2. Results of the Phase I clinical trial indicate that the drug MAXY-G34 was generally safe and well tolerated through the study.

7 , out of a maximum of 8 . 


\section{APPENDIX A continued}

Product disclosure index

IV. Future development plans

1a. Is there any plan to try the product on new diseases? $(2=$ name mentioned; $1=$ no name mentioned; $0=$ not mentioned) 1b. Is there any plan to try the product with other products? ( 2 $=$ name mentioned; $1=$ no name mentioned; $0=$ not mentioned)

2. Hemophilia.

2. Future plan for clinical trials

2a. Planned date $(1=$ mentioned; $0=$ not mentioned $)$

2 b. Number of patients for the planned trial (what disease) $(1=$ mentioned; $0=$ not mentioned)

2c. Patient information for the planned trial (what disease) $(1=$ mentioned; $0=$ not mentioned)

0. Not mentioned.

2d. Duration $(1=$ mentioned; $0=$ not mentioned $)$

2e. Method $(1=$ mentioned; $0=$ not mentioned $)$

3. Alliance $(2=$ name mentioned; $1=$ no name mentioned; $0=$ not mentioned)

Subtotal IV $=$ total scores of $[\max (1 a, 1 b)+2 a+2 b+2 c+$ $2 d+2 e+3)$

1. 2008.

0. Not mentioned.

1. Breast cancer patients.

0 . Not mentioned.

0 . Not mentioned.

2. Entered into a strategic alliance with Roche.

V. Market information

1. Number of patients affected by the disease $(1=$ mentioned; $0=$ not mentioned)

6 , out of a maximum of 9 .

2. Number of incidents (market size) $(1=$ mentioned; $0=$ not mentioned)

0 . Not mentioned.

Subtotal $V=$ total scores of $(1+2)$

0 . Not mentioned.

0 , out of a maximum of 2 .

Overall disclosure score $=$ sum of Subtotals I-V

18 , out of a maximum of 30 .

Scaled disclosure score $=$ overall disclosure score divided by

30 because MAXY-G34 is in clinical trials phase

0.60 , out of a maximum of 1.00 . 


\section{APPENDIX B}

Definitions of variables

\begin{tabular}{|c|c|}
\hline Variable name & Variable description \\
\hline$T Q$ & Tobin's Q \\
\hline Discl-Index & Disclosure Index \\
\hline Precl discl-Index & $\begin{array}{l}\text { Preclinical Disclosure } \\
\text { Index }\end{array}$ \\
\hline Technical Discl-Index & $\begin{array}{l}\text { Technical Disclosure } \\
\text { Index }\end{array}$ \\
\hline Market Discl-Index & Market Disclosure Index \\
\hline Totalprod & Total number of products \\
\hline Compl & $\begin{array}{l}\text { The first component with } \\
\text { an eigenvalue }>1 \text { from the } \\
\text { principal component } \\
\text { analysis. }\end{array}$ \\
\hline Comp2 & $\begin{array}{l}\text { The second component } \\
\text { with an eigenvalue }>1 \\
\text { from the principal } \\
\text { component analysis. }\end{array}$ \\
\hline Сотр3 & $\begin{array}{l}\text { The third component with } \\
\text { an eigenvalue }>1 \text { from the } \\
\text { principal component } \\
\text { analysis. }\end{array}$ \\
\hline Data from Com & \\
\hline
\end{tabular}

(Short-term debt + long-term debt + market value of equity)/total asset and MTBV as market value of equity/total equity.

Overall disclosure index as defined in Appendix A.

Average disclosure index related to products in an early stage of development (not yet human/clinical trials).

Average disclosure index related to the technical information (product specifications + target disease + clinical trials).

Average disclosure index related to the market information (future plans + market information).

Total number of products in development per firm/year.

The first component with an eigenvalue of 1.4 is represented by the proportion of independent directors on the board.

The second component with an eigenvalue of 1.4 is represented by the proportion of independent directors on the board.

The third component with an eigenvalue of 1.07 is represented by the proportion of independent directors on the board.

\begin{tabular}{ll} 
FirmSize & $\begin{array}{l}\text { Market value of total } \\
\text { assets }\end{array}$ \\
$T Q$ & Tobin's Q \\
Accruals & Accruals \\
Leverage & Financial Leverage \\
ListYear & Listing Year \\
FirmAge & Firm age \\
LogFirmSize & $\begin{array}{l}\text { Log of market value of } \\
\text { total assets } \\
\text { Profitability }\end{array}$ \\
\hline Loss &
\end{tabular}

Market Value of Equity (Price $\{$ PRCC_F $\} \times$ Number of Shares Outstanding $\{\mathrm{CSHO}\})+$ Total Debt [long-term debt (DLTT) + short-term debt (DLC)]

The market value of equity plus the book value of total debt divided by the book value of total assets (mvce+ lt+ esopt)/at). [Change in Current Assets (ACT) - Change in Cash (CHE) Change in Current Liabilities (LCT) - Change in Tax Payable (TXP) - Depreciation and Amortization (DP)], scaled by average Total Assets for the year.

Total Debt [long-term debt (DLTT) + short-term debt (DLC)] / Market Value of Equity (Price $\{$ PRCC_F $\} \times$ Number of Shares Outstanding $\{\mathrm{CSHO}\})$.

First year in which a firm's data are available in Compustat is the listing year.

Difference between ListYear and current year, expressed in years.

Natural logarithm of FirmSize.

A dummy variable equal to 1 if the ratio of earnings before extraordinary items (IB) to average Total Assets for the year is greater than 0 , and 0 otherwise.

All variables with prefix "L." in the tables imply lagged variables 
Table 1 Summary statistics

\begin{tabular}{lcccc}
\hline & mean & sd & min & max \\
\hline TQ & 3.458 & 2.657 & 0.369 & 15.044 \\
Discl_Index & 0.303 & 0.125 & 0.011 & 0.820 \\
Discl_Precl & 0.126 & 0.135 & 0.000 & 0.570 \\
Discl_Clinical & 0.304 & 0.145 & 0.000 & 0.610 \\
Tech_Discl & 0.213 & 0.091 & 0.000 & 0.467 \\
Market_Discl & 0.080 & 0.054 & 0.000 & 0.267 \\
Comp1 & 8.475 & 3.368 & 4.113 & 22.110 \\
Comp2 & 8.050 & 1.760 & 4.668 & 12.940 \\
Comp3 & -1.128 & 0.696 & -2.766 & 0.544 \\
Totalproduct & 6.861 & 7.023 & 0.000 & 64.000 \\
Leverage & 0.498 & 0.445 & 0.025 & 3.518 \\
FirmAge (years) & 10.612 & 6.976 & 0.000 & 30.000 \\
Loss & 0.226 & 0.418 & 0.000 & 1.000 \\
FirmSize & 4.789 & 1.668 & 1.309 & 10.503 \\
Accruals & -0.023 & 0.135 & -0.650 & 0.446 \\
$\boldsymbol{N}$ & 647 & & & \\
\hline
\end{tabular}

This table describes the univariate statistics of the main variables use in this study as well as those for the control variables in multivariate regressions. All variables are defined in Appendix B. 
Table 2 Correlation table

\begin{tabular}{|c|c|c|c|c|c|c|c|c|c|c|c|c|c|c|c|}
\hline & (1) & (2) & (3) & (4) & (5) & (6) & (7) & (8) & (9) & (10) & (11) & (12) & (13) & (14) & (15) \\
\hline TQ (1) & 1 & & & & & & & & & & & & & & \\
\hline Discl_Index(2) & 0.076 & 1 & & & & & & & & & & & & & \\
\hline Discl_Precl (3) & 0.074 & 0.010 & 1 & & & & & & & & & & & & \\
\hline Discl_Clinical (4) & 0.026 & $0.620^{* * *}$ & $-0.243^{* * *}$ & 1 & & & & & & & & & & & \\
\hline Tech_Discl (5) & 0.068 & $0.759^{* * *}$ & $0.096^{*}$ & $0.479^{* * *}$ & 1 & & & & & & & & & & \\
\hline Market_Discl (6) & 0.021 & $0.714^{* * *}$ & -0.038 & $0.550^{* * *}$ & $0.482^{* * *}$ & 1 & & & & & & & & & \\
\hline Comp1 (7) & $-0.140^{*}$ & -0.025 & -0.075 & -0.041 & 0.010 & -0.024 & 1 & & & & & & & & \\
\hline Comp2 (8) & -0.074 & $-0.175^{* *}$ & -0.076 & $-0.136^{*}$ & $-0.172^{* *}$ & $-0.153^{* *}$ & -0.012 & 1 & & & & & & & \\
\hline Comp3 (9) & $0.201^{* * *}$ & 0.019 & 0.103 & $-0.147^{* *}$ & 0.087 & -0.003 & 0.001 & -0.031 & 1 & & & & & & \\
\hline TotalProduct (10) & $-0.091^{*}$ & $-0.292^{* * *}$ & -0.010 & $-0.183^{* * *}$ & $-0.280^{* * * *}$ & $-0.222^{* * *}$ & -0.046 & $0.345^{* * *}$ & $-0.154^{* *}$ & 1 & & & & & \\
\hline Leverage (11) & $0.252^{* * *}$ & -0.064 & -0.070 & -0.052 & -0.073 & -0.010 & 0.071 & -0.066 & 0.004 & -0.031 & 1 & & & & \\
\hline FirmAge(12) & $0.102^{*}$ & $-0.117^{* *}$ & $-0.159^{* * *}$ & $-0.128^{* *}$ & $-0.124^{* *}$ & -0.075 & 0.044 & $0.153^{* *}$ & $0.108^{*}$ & $0.265^{* * *}$ & 0.010 & 1 & & & \\
\hline Loss (13) & -0.076 & $-0.176^{* * *}$ & $-0.152^{* * *}$ & $-0.154^{* * *}$ & $-0.206^{* * *}$ & $-0.147^{* * *}$ & $0.173^{* *}$ & $0.165^{* *}$ & 0.065 & $0.192^{* * *}$ & -0.051 & $0.343^{* * *}$ & 1 & & \\
\hline FirmSize(14) & -0.085 & $-0.165^{* * *}$ & $-0.115^{* *}$ & $-0.141^{* * *}$ & $-0.199^{* * *}$ & $-0.099^{*}$ & 0.09 & $0.569^{* * *}$ & -0.078 & $0.492^{* * *}$ & -0.033 & $0.394^{* * *}$ & $0.475^{* * *}$ & 1 & \\
\hline Accruals (16) & -0.018 & -0.012 & 0.018 & -0.060 & -0.011 & -0.049 & 0.029 & 0.023 & 0.028 & 0.002 & $-0.193^{* * *}$ & 0.009 & 0.075 & 0.004 & 1 \\
\hline
\end{tabular}

This table presents the correlations among the variables used in this study. All variables are defined in Appendix B.***,**, and * denote statistical significance at the $1 \%, 5 \%$, and $10 \%$ level, respectively 
Table 3 The effect of total product-disclosure index and corporate governance on firm performance

\begin{tabular}{|c|c|c|c|c|}
\hline VARIABLES & $\begin{array}{c}(1) \\
\mathrm{TQ}(\mathrm{t})\end{array}$ & $\begin{array}{c}(2) \\
\mathrm{TQ}(\mathrm{t}+1)\end{array}$ & $\begin{array}{c}(3) \\
T Q(t+2)\end{array}$ & $\begin{array}{c}(4) \\
\mathrm{TQ}(\mathrm{t}+3)\end{array}$ \\
\hline Discl_Index & $\begin{array}{l}11.149^{*} \\
(6.538)\end{array}$ & $\begin{array}{l}17.291 * * \\
(8.269)\end{array}$ & $\begin{array}{l}15.229 * \\
(8.158)\end{array}$ & $\begin{array}{c}2.361 \\
(9.715)\end{array}$ \\
\hline Comp1 & $\begin{array}{l}-0.011 \\
(0.135)\end{array}$ & $\begin{array}{l}-0.099 \\
(0.155)\end{array}$ & $\begin{array}{c}0.048 \\
(0.145)\end{array}$ & $\begin{array}{l}-0.261 \\
(0.224)\end{array}$ \\
\hline Comp2 & $\begin{array}{c}0.431^{*} \\
(0.247)\end{array}$ & $\begin{array}{l}0.572 * * \\
(0.263)\end{array}$ & $\begin{array}{l}0.652 * * \\
(0.321)\end{array}$ & $\begin{array}{c}0.381 \\
(0.286)\end{array}$ \\
\hline Comp3 & $\begin{array}{c}0.743 \\
(0.798)\end{array}$ & $\begin{array}{c}1.015 \\
(0.896)\end{array}$ & $\begin{array}{l}2.270 * * \\
(1.071)\end{array}$ & $\begin{array}{c}1.422 \\
(0.946)\end{array}$ \\
\hline Discl_Index $\times \mathrm{P} 1$ & $\begin{array}{l}-0.296 \\
(0.428)\end{array}$ & $\begin{array}{l}-0.352 \\
(0.489)\end{array}$ & $\begin{array}{l}-0.443 \\
(0.424)\end{array}$ & $\begin{array}{c}0.570 \\
(0.715)\end{array}$ \\
\hline Discl_Index $\times \mathrm{P} 2$ & $\begin{array}{l}-1.188 * * \\
(0.532)\end{array}$ & $\begin{array}{l}-2.099 * * * \\
(0.667)\end{array}$ & $\begin{array}{l}-2.616 * * * \\
(0.877)\end{array}$ & $\begin{array}{l}-1.351 \\
(0.939)\end{array}$ \\
\hline Discl_Index $\times \mathrm{P} 3$ & $\begin{array}{l}-0.885 \\
(2.083)\end{array}$ & $\begin{array}{l}-2.025 \\
(2.089)\end{array}$ & $\begin{array}{l}-5.493 * * \\
(2.373)\end{array}$ & $\begin{array}{l}-3.129 \\
(2.231)\end{array}$ \\
\hline TotalProduct & $\begin{array}{l}-0.038 \\
(0.030)\end{array}$ & $\begin{array}{l}-0.066^{*} \\
(0.034)\end{array}$ & $\begin{array}{l}-0.086^{*} \\
(0.044)\end{array}$ & $\begin{array}{l}-0.089 * \\
(0.047)\end{array}$ \\
\hline Leverage & $\begin{array}{l}1.183 * * * \\
(0.372)\end{array}$ & $\begin{array}{c}0.834^{*} \\
(0.441)\end{array}$ & $\begin{array}{c}0.442 \\
(0.565)\end{array}$ & $\begin{array}{c}0.870 \\
(0.581)\end{array}$ \\
\hline FirmAge & $\begin{array}{c}0.088^{*} \\
(0.045)\end{array}$ & $\begin{array}{c}0.066 \\
(0.050)\end{array}$ & $\begin{array}{c}0.051 \\
(0.051)\end{array}$ & $\begin{array}{c}0.032 \\
(0.056)\end{array}$ \\
\hline Loss & $\begin{array}{c}0.335 \\
(0.575)\end{array}$ & $\begin{array}{c}0.142 \\
(0.709)\end{array}$ & $\begin{array}{c}0.232 \\
(0.860)\end{array}$ & $\begin{array}{c}0.455 \\
(0.923)\end{array}$ \\
\hline LogFirmSize & $\begin{array}{l}-0.369^{*} \\
(0.212)\end{array}$ & $\begin{array}{l}-0.124 \\
(0.174)\end{array}$ & $\begin{array}{c}0.021 \\
(0.195)\end{array}$ & $\begin{array}{c}0.093 \\
(0.202)\end{array}$ \\
\hline Accruals & $\begin{array}{c}0.432 \\
(0.876)\end{array}$ & $\begin{array}{c}2.385 * * \\
(1.076)\end{array}$ & $\begin{array}{c}0.682 \\
(1.115)\end{array}$ & $\begin{array}{l}-0.816 \\
(1.036)\end{array}$ \\
\hline Constant & $\begin{array}{c}2.631 \\
(2.480)\end{array}$ & $\begin{array}{c}1.412 \\
(3.232)\end{array}$ & $\begin{array}{c}1.290 \\
(3.446)\end{array}$ & $\begin{array}{c}3.518 \\
(3.565)\end{array}$ \\
\hline Year Controls & YES & YES & YES & YES \\
\hline Observations & 307 & 299 & 284 & 276 \\
\hline R-Squared & 0.178 & 0.265 & 0.241 & 0.189 \\
\hline
\end{tabular}

This table presents examines the effects of disclosures and corporate governance on firm performance in a multivariate regression. Robust standard errors are presented in parentheses. All variables are defined in Appendix B.***, **, and * denote statistical significance at the $1 \%, 5 \%$, and $10 \%$ level, respectively. 
Table 4 The effect of preclinical product-disclosure and corporate governance on firm performance

\begin{tabular}{|c|c|c|c|c|}
\hline VARIABLES & $\begin{array}{c}(1) \\
\mathrm{TQ}(\mathrm{t})\end{array}$ & $\begin{array}{c}(2) \\
T Q(t+1)\end{array}$ & $\begin{array}{c}(3) \\
T Q(t+2)\end{array}$ & $\begin{array}{c}(4) \\
T Q(t+3)\end{array}$ \\
\hline Discl_Precl & $\begin{array}{c}4.599 \\
(7.226)\end{array}$ & $\begin{array}{l}-0.851 \\
(9.583)\end{array}$ & $\begin{array}{c}-4.733 \\
(10.462)\end{array}$ & $\begin{array}{l}-2.812 \\
(9.381)\end{array}$ \\
\hline Comp1 & $\begin{array}{l}-0.079 \\
(0.066)\end{array}$ & $\begin{array}{l}-0.254 * * * \\
(0.086)\end{array}$ & $\begin{array}{l}-0.195^{* * *} \\
(0.071)\end{array}$ & $\begin{array}{l}-0.106 \\
(0.080)\end{array}$ \\
\hline Comp2 & $\begin{array}{c}0.058 \\
(0.166)\end{array}$ & $\begin{array}{l}-0.091 \\
(0.176)\end{array}$ & $\begin{array}{l}-0.197 \\
(0.198)\end{array}$ & $\begin{array}{l}-0.068 \\
(0.191)\end{array}$ \\
\hline Comp3 & $\begin{array}{c}0.351 \\
(0.349)\end{array}$ & $\begin{array}{c}0.337 \\
(0.533)\end{array}$ & $\begin{array}{c}0.363 \\
(0.489)\end{array}$ & $\begin{array}{c}0.380 \\
(0.607)\end{array}$ \\
\hline Discl_Precl×P1 & $\begin{array}{l}-0.198 \\
(0.369)\end{array}$ & $\begin{array}{c}0.381 \\
(0.428)\end{array}$ & $\begin{array}{l}0.726^{* *} \\
(0.349)\end{array}$ & $\begin{array}{c}0.039 \\
(0.444)\end{array}$ \\
\hline Discl_Precl $\times$ P2 & $\begin{array}{c}0.072 \\
(0.870)\end{array}$ & $\begin{array}{c}0.088 \\
(0.956)\end{array}$ & $\begin{array}{c}0.325 \\
(1.060)\end{array}$ & $\begin{array}{c}0.442 \\
(0.945)\end{array}$ \\
\hline Discl_Precl×P3 & $\begin{array}{c}0.895 \\
(1.514)\end{array}$ & $\begin{array}{c}0.704 \\
(1.683)\end{array}$ & $\begin{array}{c}1.969 \\
(1.535)\end{array}$ & $\begin{array}{c}0.560 \\
(1.660)\end{array}$ \\
\hline TotalProduct & $\begin{array}{l}-0.027 \\
(0.026)\end{array}$ & $\begin{array}{l}-0.041 \\
(0.030)\end{array}$ & $\begin{array}{l}-0.046 \\
(0.043)\end{array}$ & $\begin{array}{l}-0.069^{*} \\
(0.040)\end{array}$ \\
\hline Leverage & $\begin{array}{l}1.210^{* * *} \\
(0.366)\end{array}$ & $\begin{array}{c}0.866^{*} \\
(0.437)\end{array}$ & $\begin{array}{c}0.635 \\
(0.567)\end{array}$ & $\begin{array}{c}0.794 \\
(0.596)\end{array}$ \\
\hline FirmAge & $\begin{array}{c}0.081 * \\
(0.046)\end{array}$ & $\begin{array}{c}0.051 \\
(0.053)\end{array}$ & $\begin{array}{c}0.029 \\
(0.060)\end{array}$ & $\begin{array}{c}0.013 \\
(0.058)\end{array}$ \\
\hline Loss & $\begin{array}{c}0.395 \\
(0.643)\end{array}$ & $\begin{array}{c}0.301 \\
(0.799)\end{array}$ & $\begin{array}{c}0.583 \\
(0.943)\end{array}$ & $\begin{array}{c}0.530 \\
(0.966)\end{array}$ \\
\hline LogFirmSize & $\begin{array}{l}-0.295 \\
(0.217)\end{array}$ & $\begin{array}{l}-0.062 \\
(0.213)\end{array}$ & $\begin{array}{c}0.070 \\
(0.230)\end{array}$ & $\begin{array}{c}0.111 \\
(0.226)\end{array}$ \\
\hline Accruals & $\begin{array}{c}0.597 \\
(0.925)\end{array}$ & $\begin{array}{l}2.959^{* * * *} \\
(1.011)\end{array}$ & $\begin{array}{l}2.172 * \\
(1.137)\end{array}$ & $\begin{array}{l}-0.298 \\
(1.010)\end{array}$ \\
\hline Constant & $\begin{array}{l}4.963 * * * \\
(1.322)\end{array}$ & $\begin{array}{l}6.510^{* * *} \\
(2.204)\end{array}$ & $\begin{array}{l}6.347 * * * \\
(2.196)\end{array}$ & $\begin{array}{l}4.338 * * \\
(2.092)\end{array}$ \\
\hline Year Controls & YES & YES & YES & YES \\
\hline Observations & 309 & 301 & 285 & 277 \\
\hline R-Squared & 0.185 & 0.239 & 0.187 & 0.164 \\
\hline
\end{tabular}

This table presents examines the effects of preclinical product-disclosure and corporate governance on firm performance in a multivariate regression. Robust standard errors are presented in parentheses. All variables are defined in Appendix B.***, **, and * denote statistical significance at the 1\%, 5\%, and $10 \%$ level, respectively. 
Table 5 The effect of technical product-disclosure and corporate governance on firm performance

\begin{tabular}{|c|c|c|c|c|}
\hline VARIABLES & $\begin{array}{l}\text { (1) } \\
\text { TQ }\end{array}$ & $\begin{array}{c}(2) \\
T Q(t+1)\end{array}$ & $\begin{array}{c}(3) \\
T Q(t+2)\end{array}$ & $\begin{array}{c}(4) \\
T Q(t+3)\end{array}$ \\
\hline Tech_Discl & $\begin{array}{l}21.102 * * \\
(8.559)\end{array}$ & $\begin{array}{l}30.548 * * \\
(14.729)\end{array}$ & $\begin{array}{c}23.223^{*} \\
(12.501)\end{array}$ & $\begin{array}{r}6.732 \\
(12.872)\end{array}$ \\
\hline Comp1 & $\begin{array}{l}-0.066 \\
(0.124)\end{array}$ & $\begin{array}{l}-0.007 \\
(0.186)\end{array}$ & $\begin{array}{c}0.004 \\
(0.134)\end{array}$ & $\begin{array}{l}-0.250 \\
(0.190)\end{array}$ \\
\hline Comp2 & $\begin{array}{l}0.618 * * \\
(0.254)\end{array}$ & $\begin{array}{l}0.625^{* *} \\
(0.296)\end{array}$ & $\begin{array}{c}0.703^{*} \\
(0.355)\end{array}$ & $\begin{array}{c}0.305 \\
(0.274)\end{array}$ \\
\hline Comp3 & $\begin{array}{c}0.026 \\
(0.749)\end{array}$ & $\begin{array}{c}0.342 \\
(0.917)\end{array}$ & $\begin{array}{c}1.614 \\
(1.050)\end{array}$ & $\begin{array}{c}0.217 \\
(0.897)\end{array}$ \\
\hline Tech_Discl $\times \mathrm{P} 1$ & $\begin{array}{l}-0.115 \\
(0.562)\end{array}$ & $\begin{array}{l}-0.866 \\
(0.840)\end{array}$ & $\begin{array}{l}-0.427 \\
(0.577)\end{array}$ & $\begin{array}{c}0.692 \\
(0.822)\end{array}$ \\
\hline Tech_Discl $\times \mathrm{P} 2$ & $\begin{array}{l}-2.445 * * * \\
(0.828)\end{array}$ & $\begin{array}{l}-2.998 * * \\
(1.239)\end{array}$ & $\begin{array}{l}-3.710 * * \\
(1.518)\end{array}$ & $\begin{array}{l}-1.469 \\
(1.335)\end{array}$ \\
\hline Tech_Discl $\times$ P3 & $\begin{array}{c}2.297 \\
(2.657)\end{array}$ & $\begin{array}{c}0.589 \\
(3.045)\end{array}$ & $\begin{array}{l}-4.120 \\
(3.263)\end{array}$ & $\begin{array}{c}1.247 \\
(2.802)\end{array}$ \\
\hline TotalProduct & $\begin{array}{l}-0.057 * \\
(0.032)\end{array}$ & $\begin{array}{l}-0.073^{*} \\
(0.038)\end{array}$ & $\begin{array}{l}-0.094 * \\
(0.050)\end{array}$ & $\begin{array}{l}-0.093 * \\
(0.048)\end{array}$ \\
\hline Leverage & $\begin{array}{l}1.202 * * * \\
(0.337)\end{array}$ & $\begin{array}{l}0.823^{*} \\
\quad(0.428)\end{array}$ & $\begin{array}{c}0.463 \\
(0.548)\end{array}$ & $\begin{array}{c}0.928 \\
(0.587)\end{array}$ \\
\hline FirmAge & $\begin{array}{c}0.080 * \\
(0.042)\end{array}$ & $\begin{array}{c}0.055 \\
(0.048)\end{array}$ & $\begin{array}{c}0.029 \\
(0.053)\end{array}$ & $\begin{array}{c}0.016 \\
(0.055)\end{array}$ \\
\hline Loss & $\begin{array}{c}0.372 \\
(0.522)\end{array}$ & $\begin{array}{c}0.300 \\
(0.694)\end{array}$ & $\begin{array}{c}0.337 \\
(0.823)\end{array}$ & $\begin{array}{c}0.530 \\
(0.880)\end{array}$ \\
\hline LogFirmSize & $\begin{array}{l}-0.401 * \\
(0.210)\end{array}$ & $\begin{array}{l}-0.177 \\
(0.186)\end{array}$ & $\begin{array}{l}-0.006 \\
(0.214)\end{array}$ & $\begin{array}{c}0.084 \\
(0.204)\end{array}$ \\
\hline Accruals & $\begin{array}{c}0.250 \\
(0.869)\end{array}$ & $\begin{array}{l}2.568 * * \\
(1.001)\end{array}$ & $\begin{array}{c}1.091 \\
(1.122)\end{array}$ & $\begin{array}{l}-0.562 \\
(0.957)\end{array}$ \\
\hline Constant & $\begin{array}{c}1.564 \\
(2.177)\end{array}$ & $\begin{array}{c}0.098 \\
(3.295)\end{array}$ & $\begin{array}{c}1.068 \\
(3.129)\end{array}$ & $\begin{array}{c}2.845 \\
(3.175)\end{array}$ \\
\hline Year Controls & YES & YES & YES & YES \\
\hline Observations & 313 & 305 & 289 & 281 \\
\hline R-Squared & 0.192 & 0.256 & 0.214 & 0.173 \\
\hline
\end{tabular}

This table presents examines the effects of technical product-disclosure and corporate governance on firm performance in a multivariate regression. Robust standard errors are presented in parentheses. All variables are defined in Appendix B.***,**, and * denote statistical significance at the $1 \%, 5 \%$, and $10 \%$ level, respectively. 
Table 6 The effect of total product-disclosure index and corporate governance on firm performance after controlling for institutional ownership

\begin{tabular}{|c|c|c|c|c|}
\hline VARIABLES & $\begin{array}{l}(1) \\
\mathrm{TQ}\end{array}$ & $\begin{array}{c}(2) \\
\mathrm{TQ}+1 \\
\end{array}$ & $\begin{array}{c}(3) \\
\mathrm{TQ}+2 \\
\end{array}$ & $\begin{array}{c}(4) \\
\mathrm{TQ}+3 \\
\end{array}$ \\
\hline Discl_Index & $\begin{array}{l}11.532 * \\
{[6.386]}\end{array}$ & $\begin{array}{c}17.507 * * \\
{[8.056]}\end{array}$ & $\begin{array}{l}15.467 * \\
{[7.976]}\end{array}$ & $\begin{array}{c}2.659 \\
{[9.605]}\end{array}$ \\
\hline Comp1 & $\begin{array}{c}-0.041 \\
{[0.138]}\end{array}$ & $\begin{array}{c}-0.115 \\
{[0.156]}\end{array}$ & $\begin{array}{c}0.038 \\
{[0.148]}\end{array}$ & $\begin{array}{c}-0.271 \\
{[0.229]}\end{array}$ \\
\hline Comp2 & $\begin{array}{c}0.539^{* *} \\
{[0.243]}\end{array}$ & $\begin{array}{c}0.631 * * \\
{[0.256]}\end{array}$ & $\begin{array}{c}0.700^{* *} \\
{[0.314]}\end{array}$ & $\begin{array}{c}0.425 \\
{[0.287]}\end{array}$ \\
\hline Comp3 & $\begin{array}{c}0.716 \\
{[0.808]}\end{array}$ & $\begin{array}{c}0.995 \\
{[0.897]}\end{array}$ & $\begin{array}{l}2.244 * * \\
{[1.064]}\end{array}$ & $\begin{array}{c}1.397 \\
{[0.947]}\end{array}$ \\
\hline Discl_index $\times p 1$ & $\begin{array}{c}-0.202 \\
{[0.443]}\end{array}$ & $\begin{array}{c}-0.302 \\
{[0.495]}\end{array}$ & $\begin{array}{c}-0.406 \\
{[0.433]}\end{array}$ & $\begin{array}{c}0.603 \\
{[0.731]}\end{array}$ \\
\hline Discl_inde $x \times p 2$ & $\begin{array}{c}-1.331 * * \\
{[0.529]}\end{array}$ & $\begin{array}{c}-2.173^{* * *} \\
{[0.646]}\end{array}$ & $\begin{array}{c}-2.674 * * * \\
{[0.853]}\end{array}$ & $\begin{array}{l}-1.407 \\
{[0.932]}\end{array}$ \\
\hline Discl_inde $x \times$ p3 & $\begin{array}{c}-0.848 \\
{[2.100]}\end{array}$ & $\begin{array}{l}-1.993 \\
{[2.070]}\end{array}$ & $\begin{array}{c}-5.426 * * \\
{[2.347]}\end{array}$ & $\begin{array}{l}-3.069 \\
{[2.219]}\end{array}$ \\
\hline Totalproduct & $\begin{array}{l}-0.021 \\
{[0.030]}\end{array}$ & $\begin{array}{l}-0.056 * \\
{[0.033]}\end{array}$ & $\begin{array}{l}-0.078^{*} \\
{[0.043]}\end{array}$ & $\begin{array}{l}-0.082^{*} \\
{[0.044]}\end{array}$ \\
\hline Leverage & $\begin{array}{c}1.052 * * * \\
{[0.356]}\end{array}$ & $\begin{array}{c}0.767 * \\
{[0.433]}\end{array}$ & $\begin{array}{c}0.381 \\
{[0.597]}\end{array}$ & $\begin{array}{c}0.820 \\
{[0.614]}\end{array}$ \\
\hline FirmAge & $\begin{array}{c}0.091 * * \\
{[0.044]}\end{array}$ & $\begin{array}{c}0.067 \\
{[0.049]}\end{array}$ & $\begin{array}{c}0.051 \\
{[0.051]}\end{array}$ & $\begin{array}{c}0.033 \\
{[0.055]}\end{array}$ \\
\hline Loss & $\begin{array}{c}0.391 \\
{[0.511]}\end{array}$ & $\begin{array}{c}0.174 \\
{[0.680]}\end{array}$ & $\begin{array}{c}0.254 \\
{[0.844]}\end{array}$ & $\begin{array}{c}0.482 \\
{[0.915]}\end{array}$ \\
\hline LogFirmSize & $\begin{array}{c}-0.688 * * * \\
{[0.205]}\end{array}$ & $\begin{array}{c}-0.298 \\
{[0.179]}\end{array}$ & $\begin{array}{c}-0.119 \\
{[0.222]}\end{array}$ & $\begin{array}{c}-0.028 \\
{[0.225]}\end{array}$ \\
\hline Accruals & $\begin{array}{c}0.409 \\
{[0.835]}\end{array}$ & $\begin{array}{l}2.397 * * \\
{[1.083]}\end{array}$ & $\begin{array}{c}0.694 \\
{[1.116]}\end{array}$ & $\begin{array}{c}-0.771 \\
{[1.031]}\end{array}$ \\
\hline Instown_perc & $\begin{array}{c}1.772 * * * \\
{[0.560]}\end{array}$ & $\begin{array}{c}0.954 \\
{[0.650]}\end{array}$ & $\begin{array}{c}0.766 \\
{[0.766]}\end{array}$ & $\begin{array}{c}0.660 \\
{[0.745]}\end{array}$ \\
\hline Constant & $\begin{array}{c}2.676 \\
{[2.447]}\end{array}$ & $\begin{array}{c}1.437 \\
{[3.174]}\end{array}$ & $\begin{array}{c}1.268 \\
{[3.382]}\end{array}$ & $\begin{array}{c}3.476 \\
{[3.527]}\end{array}$ \\
\hline Year Controls & YES & YES & YES & YES \\
\hline Observations & 307 & 299 & 284 & 276 \\
\hline R-squared & 0.216 & 0.272 & 0.246 & 0.192 \\
\hline
\end{tabular}

This table presents examines the effects of total product-disclosure index and corporate governance on firm performance in a multivariate regression after controlling for institutional ownership. Robust standard errors are presented in parentheses. All variables are defined in Appendix B.***,**, and * denote statistical significance at the $1 \%, 5 \%$, and $10 \%$ level, respectively. 
Table 7 The effect of preclinical product-disclosure index and corporate governance on firm performance after controlling for institutional ownership

\begin{tabular}{|c|c|c|c|c|}
\hline VARIABLES & $\begin{array}{l}\text { (1) } \\
\mathrm{TQ}\end{array}$ & $\begin{array}{c}(2) \\
\mathrm{TQ}+1 \\
\end{array}$ & $\begin{array}{c}(3) \\
\mathrm{TQ}+2 \\
\end{array}$ & $\begin{array}{c}(4) \\
\mathrm{TQ}+3 \\
\end{array}$ \\
\hline Discl_Precl & $\begin{array}{c}6.088 \\
{[6.923]}\end{array}$ & $\begin{array}{c}-0.130 \\
{[9.581]}\end{array}$ & $\begin{array}{c}-4.014 \\
{[10.603]}\end{array}$ & $\begin{array}{l}-2.121 \\
{[9.256]}\end{array}$ \\
\hline Comp1 & $\begin{array}{c}-0.066 \\
{[0.059]}\end{array}$ & $\begin{array}{c}-0.248 * * * \\
{[0.086]}\end{array}$ & $\begin{array}{c}-0.185^{* *} \\
{[0.070]}\end{array}$ & $\begin{array}{l}-0.100 \\
{[0.080]}\end{array}$ \\
\hline Comp2 & $\begin{array}{c}0.125 \\
{[0.158]}\end{array}$ & $\begin{array}{c}-0.059 \\
{[0.180]}\end{array}$ & $\begin{array}{c}-0.167 \\
{[0.205]}\end{array}$ & $\begin{array}{l}-0.040 \\
{[0.192]}\end{array}$ \\
\hline Comp3 & $\begin{array}{c}0.291 \\
{[0.357]}\end{array}$ & $\begin{array}{c}0.312 \\
{[0.542]}\end{array}$ & $\begin{array}{c}0.345 \\
{[0.493]}\end{array}$ & $\begin{array}{c}0.360 \\
{[0.615]}\end{array}$ \\
\hline Discl_Precl $\times \mathrm{P} 1$ & $\begin{array}{c}-0.294 \\
{[0.346]}\end{array}$ & $\begin{array}{c}0.336 \\
{[0.425]}\end{array}$ & $\begin{array}{l}0.675^{*} \\
{[0.356]}\end{array}$ & $\begin{array}{c}-0.006 \\
{[0.453]}\end{array}$ \\
\hline Discl_Precl $\times \mathrm{P} 2$ & $\begin{array}{c}0.030 \\
{[0.845]}\end{array}$ & $\begin{array}{c}0.063 \\
{[0.941]}\end{array}$ & $\begin{array}{c}0.306 \\
{[1.051]}\end{array}$ & $\begin{array}{c}0.421 \\
{[0.931]}\end{array}$ \\
\hline Discl_Precl×P3 & $\begin{array}{c}1.032 \\
{[1.483]}\end{array}$ & $\begin{array}{c}0.746 \\
{[1.647]}\end{array}$ & $\begin{array}{c}1.976 \\
{[1.499]}\end{array}$ & $\begin{array}{c}0.600 \\
{[1.646]}\end{array}$ \\
\hline TotalProduct & $\begin{array}{c}-0.009 \\
{[0.026]}\end{array}$ & $\begin{array}{c}-0.032 \\
{[0.029]}\end{array}$ & $\begin{array}{c}-0.038 \\
{[0.041]}\end{array}$ & $\begin{array}{l}-0.062 * \\
{[0.037]}\end{array}$ \\
\hline Leverage & $\begin{array}{c}1.065 * * * \\
{[0.354]}\end{array}$ & $\begin{array}{c}0.805^{*} \\
{[0.435]}\end{array}$ & $\begin{array}{c}0.571 \\
{[0.601]}\end{array}$ & $\begin{array}{c}0.737 \\
{[0.635]}\end{array}$ \\
\hline FirmAge & $\begin{array}{c}0.086^{*} \\
{[0.046]}\end{array}$ & $\begin{array}{c}0.053 \\
{[0.053]}\end{array}$ & $\begin{array}{c}0.030 \\
{[0.060]}\end{array}$ & $\begin{array}{c}0.014 \\
{[0.058]}\end{array}$ \\
\hline Loss & $\begin{array}{c}0.451 \\
{[0.596]}\end{array}$ & $\begin{array}{c}0.328 \\
{[0.778]}\end{array}$ & $\begin{array}{c}0.602 \\
{[0.928]}\end{array}$ & $\begin{array}{c}0.553 \\
{[0.961]}\end{array}$ \\
\hline LogFirmSize & $\begin{array}{c}-0.611 * * * \\
{[0.226]}\end{array}$ & $\begin{array}{c}-0.207 \\
{[0.225]}\end{array}$ & $\begin{array}{c}-0.059 \\
{[0.251]}\end{array}$ & $\begin{array}{l}-0.004 \\
{[0.255]}\end{array}$ \\
\hline Accruals & $\begin{array}{c}0.572 \\
{[0.883]}\end{array}$ & $\begin{array}{c}2.965^{* * *} * \\
{[1.013]}\end{array}$ & $\begin{array}{l}2.177^{*} \\
{[1.130]}\end{array}$ & $\begin{array}{c}-0.268 \\
{[1.013]}\end{array}$ \\
\hline Instown_perc & $\begin{array}{c}1.780 * * * \\
{[0.586]}\end{array}$ & $\begin{array}{c}0.807 \\
{[0.736]}\end{array}$ & $\begin{array}{c}0.716 \\
{[0.814]}\end{array}$ & $\begin{array}{c}0.641 \\
{[0.815]}\end{array}$ \\
\hline Constant & $\begin{array}{c}4.820 * * * \\
{[1.260]}\end{array}$ & $\begin{array}{c}6.443 * * * \\
{[2.194]}\end{array}$ & $\begin{array}{c}6.247 * * * \\
{[2.193]}\end{array}$ & $\begin{array}{l}4.258^{* *} \\
{[2.094]}\end{array}$ \\
\hline Year Controls & YES & YES & YES & YES \\
\hline Observations & 309 & 301 & 285 & 277 \\
\hline R-squared & 0.223 & 0.244 & 0.191 & 0.167 \\
\hline
\end{tabular}

This table presents examines the effects of preclinical product-disclosure index and corporate governance on firm performance in a multivariate regression after controlling for institutional ownership. Robust standard errors are presented in parentheses. All variables are defined in Appendix B.***,**, and * denote statistical significance at the $1 \%, 5 \%$, and $10 \%$ level, respectively. 
Table 8 The effect of technical product-disclosure index and corporate governance on firm performance after controlling for institutional ownership

\begin{tabular}{|c|c|c|c|c|}
\hline VARIABLES & $\begin{array}{l}(1) \\
\text { TQ }\end{array}$ & $\begin{array}{c}(2) \\
\mathrm{TQ}+1 \\
\end{array}$ & $\begin{array}{c}(3) \\
\mathrm{TQ}+2 \\
\end{array}$ & $\begin{array}{c}(4) \\
\mathrm{TQ}+3 \\
\end{array}$ \\
\hline Tech_Discl & $\begin{array}{c}22.901 * * * \\
{[8.123]}\end{array}$ & $\begin{array}{c}31.532 * * \\
{[14.500]}\end{array}$ & $\begin{array}{l}24.049 * \\
{[12.310]}\end{array}$ & $\begin{array}{c}7.549 \\
{[12.722]}\end{array}$ \\
\hline Comp1 & $\begin{array}{c}-0.070 \\
{[0.125]}\end{array}$ & $\begin{array}{c}-0.010 \\
{[0.187]}\end{array}$ & $\begin{array}{c}0.003 \\
{[0.135]}\end{array}$ & $\begin{array}{c}-0.250 \\
{[0.191]}\end{array}$ \\
\hline Comp2 & $\begin{array}{c}0.736 * * * \\
{[0.242]}\end{array}$ & $\begin{array}{c}0.690 * * \\
{[0.284]}\end{array}$ & $\begin{array}{c}0.759 * * \\
{[0.349]}\end{array}$ & $\begin{array}{c}0.351 \\
{[0.271]}\end{array}$ \\
\hline Comp3 & $\begin{array}{c}0.123 \\
{[0.730]}\end{array}$ & $\begin{array}{c}0.387 \\
{[0.903]}\end{array}$ & $\begin{array}{c}1.650 \\
{[1.046]}\end{array}$ & $\begin{array}{c}0.251 \\
{[0.890]}\end{array}$ \\
\hline Tech_Discl $\times$ P1 & $\begin{array}{c}-0.103 \\
{[0.566]}\end{array}$ & $\begin{array}{c}-0.858 \\
{[0.851]}\end{array}$ & $\begin{array}{c}-0.415 \\
{[0.584]}\end{array}$ & $\begin{array}{c}0.691 \\
{[0.828]}\end{array}$ \\
\hline Tech_Discl $\times \mathrm{P} 2$ & $\begin{array}{c}-2.672 * * * \\
{[0.790]}\end{array}$ & $\begin{array}{c}-3.119 * * \\
{[1.199]}\end{array}$ & $\begin{array}{c}-3.811 * * \\
{[1.483]}\end{array}$ & $\begin{array}{c}-1.553 \\
{[1.312]}\end{array}$ \\
\hline Tech_Discl×P3 & $\begin{array}{c}1.781 \\
{[2.599]}\end{array}$ & $\begin{array}{c}0.338 \\
{[2.983]}\end{array}$ & $\begin{array}{c}-4.310 \\
{[3.250]}\end{array}$ & $\begin{array}{c}1.064 \\
{[2.779]}\end{array}$ \\
\hline TotalProduct & $\begin{array}{c}-0.037 \\
{[0.032]}\end{array}$ & $\begin{array}{c}-0.063 * \\
{[0.036]}\end{array}$ & $\begin{array}{c}-0.085^{*} \\
{[0.049]}\end{array}$ & $\begin{array}{c}-0.085^{*} \\
{[0.045]}\end{array}$ \\
\hline Leverage & $\begin{array}{c}1.091 * * * \\
{[0.326]}\end{array}$ & $\begin{array}{c}0.766^{*} \\
{[0.426]}\end{array}$ & $\begin{array}{c}0.408 \\
{[0.580]}\end{array}$ & $\begin{array}{c}0.887 \\
{[0.615]}\end{array}$ \\
\hline FirmAge & $\begin{array}{c}0.086^{* *} \\
{[0.040]}\end{array}$ & $\begin{array}{c}0.057 \\
{[0.047]}\end{array}$ & $\begin{array}{c}0.031 \\
{[0.052]}\end{array}$ & $\begin{array}{c}0.018 \\
{[0.054]}\end{array}$ \\
\hline Loss & $\begin{array}{c}0.468 \\
{[0.475]}\end{array}$ & $\begin{array}{c}0.355 \\
{[0.671]}\end{array}$ & $\begin{array}{c}0.378 \\
{[0.811]}\end{array}$ & $\begin{array}{c}0.573 \\
{[0.880]}\end{array}$ \\
\hline LogFirmSize & $\begin{array}{c}-0.734 * * * \\
{[0.207]}\end{array}$ & $\begin{array}{l}-0.361^{*} \\
{[0.186]}\end{array}$ & $\begin{array}{c}-0.160 \\
{[0.240]}\end{array}$ & $\begin{array}{c}-0.041 \\
{[0.224]}\end{array}$ \\
\hline Accruals & $\begin{array}{c}0.294 \\
{[0.838]}\end{array}$ & $\begin{array}{c}2.612 * * \\
{[1.010]}\end{array}$ & $\begin{array}{c}1.134 \\
{[1.129]}\end{array}$ & $\begin{array}{c}-0.491 \\
{[0.949]}\end{array}$ \\
\hline Instown_perc & $\begin{array}{c}1.792 * * * \\
{[0.523]}\end{array}$ & $\begin{array}{c}0.977 \\
{[0.630]}\end{array}$ & $\begin{array}{c}0.818 \\
{[0.730]}\end{array}$ & $\begin{array}{c}0.661 \\
{[0.694]}\end{array}$ \\
\hline Constant & $\begin{array}{c}1.335 \\
{[2.113]}\end{array}$ & $\begin{array}{c}-0.024 \\
{[3.253]}\end{array}$ & $\begin{array}{c}0.949 \\
{[3.063]}\end{array}$ & $\begin{array}{c}2.717 \\
{[3.136]}\end{array}$ \\
\hline Year Controls & YES & YES & YES & YES \\
\hline Observations & 313 & 305 & 289 & 281 \\
\hline R-squared & 0.230 & 0.264 & 0.219 & 0.177 \\
\hline
\end{tabular}

This table presents examines the effects of technical product-disclosure index and corporate governance on firm performance in a multivariate regression after controlling for institutional ownership. Robust standard errors are presented in parentheses. All variables are defined in Appendix B.***, **, and $*$ denote statistical significance at the $1 \%, 5 \%$, and $10 \%$ level, respectively. 
Table 9 The effect of lagged total product-disclosure index and corporate governance on firm performance

\begin{tabular}{|c|c|c|c|c|}
\hline VARIABLES & $\begin{array}{l}(1) \\
\mathrm{TQ}\end{array}$ & $\begin{array}{c}(2) \\
\mathrm{TQ}(\mathrm{t}+1) \\
\end{array}$ & $\begin{array}{c}(3) \\
T Q(t+2) \\
\end{array}$ & $\begin{array}{c}(4) \\
\mathrm{TQ}(\mathrm{t}+3) \\
\end{array}$ \\
\hline Discl_Index & $\begin{array}{c}14.663^{* *} \\
{[6.101]}\end{array}$ & $\begin{array}{c}22.337 * * * \\
{[7.669]}\end{array}$ & $\begin{array}{l}16.513^{*} \\
{[8.874]}\end{array}$ & $\begin{array}{l}12.861 \\
{[9.397]}\end{array}$ \\
\hline L.Comp1 & $\begin{array}{c}-0.106 \\
{[0.099]}\end{array}$ & $\begin{array}{c}-0.010 \\
{[0.128]}\end{array}$ & $\begin{array}{c}-0.046 \\
{[0.149]}\end{array}$ & $\begin{array}{c}-0.052 \\
{[0.152]}\end{array}$ \\
\hline L.Comp2 & $\begin{array}{c}0.497 * * \\
{[0.243]}\end{array}$ & $\begin{array}{c}0.865^{* *} \\
{[0.328]}\end{array}$ & $\begin{array}{c}0.863^{* *} \\
{[0.353]}\end{array}$ & $\begin{array}{l}0.608^{*} \\
{[0.350]}\end{array}$ \\
\hline L.Comp3 & $\begin{array}{c}0.648 \\
{[1.010]}\end{array}$ & $\begin{array}{c}1.283 \\
{[1.001]}\end{array}$ & $\begin{array}{c}1.684 \\
{[1.131]}\end{array}$ & $\begin{array}{c}1.150 \\
{[0.706]}\end{array}$ \\
\hline L.Comp $1 *$ Discl_Index & $\begin{array}{c}-0.029 \\
{[0.278]}\end{array}$ & $\begin{array}{c}-0.320 \\
{[0.316]}\end{array}$ & $\begin{array}{c}-0.227 \\
{[0.338]}\end{array}$ & $\begin{array}{c}-0.289 \\
{[0.398]}\end{array}$ \\
\hline L.Comp2*Discl_Index & $\begin{array}{c}-1.809 * * * \\
{[0.668]}\end{array}$ & $\begin{array}{c}-2.928 * * * \\
{[0.836]}\end{array}$ & $\begin{array}{c}-2.754 * * * \\
{[0.992]}\end{array}$ & $\begin{array}{c}-1.693 \\
{[1.232]}\end{array}$ \\
\hline L.Comp3*Discl_Index & $\begin{array}{c}-0.732 \\
{[2.302]}\end{array}$ & $\begin{array}{l}-2.750 \\
{[2.169]}\end{array}$ & $\begin{array}{c}-4.098 \\
{[2.670]}\end{array}$ & $\begin{array}{c}-2.798 \\
{[1.797]}\end{array}$ \\
\hline TotalProduct & $\begin{array}{l}-0.053^{*} \\
{[0.030]}\end{array}$ & $\begin{array}{c}-0.071 * * \\
{[0.028]}\end{array}$ & $\begin{array}{c}-0.085^{* * *} \\
{[0.031]}\end{array}$ & $\begin{array}{c}-0.081 * * \\
{[0.035]}\end{array}$ \\
\hline Leverage & $\begin{array}{c}1.294 * * * \\
{[0.401]}\end{array}$ & $\begin{array}{l}1.147 * * \\
{[0.522]}\end{array}$ & $\begin{array}{l}1.312^{* *} \\
{[0.498]}\end{array}$ & $\begin{array}{c}1.288 * * \\
{[0.536]}\end{array}$ \\
\hline FirmAge & $\begin{array}{l}0.086^{*} \\
{[0.045]}\end{array}$ & $\begin{array}{c}0.095^{* *} \\
{[0.044]}\end{array}$ & $\begin{array}{l}0.081 * \\
{[0.047]}\end{array}$ & $\begin{array}{c}0.047 \\
{[0.051]}\end{array}$ \\
\hline Loss & $\begin{array}{c}0.151 \\
{[0.567]}\end{array}$ & $\begin{array}{c}0.128 \\
{[0.669]}\end{array}$ & $\begin{array}{c}-0.302 \\
{[0.675]}\end{array}$ & $\begin{array}{c}0.118 \\
{[0.740]}\end{array}$ \\
\hline LogFirmSize & $\begin{array}{c}-0.192 \\
{[0.163]}\end{array}$ & $\begin{array}{l}-0.289^{*} \\
{[0.150]}\end{array}$ & $\begin{array}{c}-0.191 \\
{[0.211]}\end{array}$ & $\begin{array}{c}-0.186 \\
{[0.217]}\end{array}$ \\
\hline Accruals & $\begin{array}{c}-0.258 \\
{[1.228]}\end{array}$ & $\begin{array}{l}-1.390 \\
{[1.492]}\end{array}$ & $\begin{array}{c}1.343 \\
{[2.369]}\end{array}$ & $\begin{array}{c}0.963 \\
{[2.092]}\end{array}$ \\
\hline Constant & $\begin{array}{c}2.623 \\
{[2.464]}\end{array}$ & $\begin{array}{c}0.086 \\
{[3.022]}\end{array}$ & $\begin{array}{c}-0.001 \\
{[3.193]}\end{array}$ & $\begin{array}{c}0.735 \\
{[3.121]}\end{array}$ \\
\hline Year Controls & YES & YES & YES & YES \\
\hline Observations & 248 & 244 & 231 & 231 \\
\hline R-squared & 0.248 & 0.300 & 0.257 & 0.191 \\
\hline
\end{tabular}

This table presents examines the effects of lagged total product-disclosure index and corporate governance on firm performance in a multivariate regression. Robust standard errors are presented in parentheses. All variables are defined in Appendix B.***, **, and $*$ denote statistical significance at the $1 \%, 5 \%$, and $10 \%$ level, respectively. 
Table 10 The effect of lagged preclinical-disclosure index and corporate governance on firm performance

\begin{tabular}{|c|c|c|c|c|}
\hline & (1) & (2) & (3) & (4) \\
\hline VARIABLES & TQ & $\mathrm{TQ}(\mathrm{t}+1)$ & $\mathrm{TQ}(\mathrm{t}+2)$ & $\mathrm{TQ}(\mathrm{t}+3)$ \\
\hline \multirow[t]{2}{*}{ Discl_Precl } & 12.204 & 5.468 & 3.064 & -12.660 \\
\hline & [8.940] & [12.284] & {$[10.741]$} & [9.943] \\
\hline \multirow[t]{2}{*}{ L.Comp1 } & -0.080 & $-0.148^{*}$ & $-0.149 * *$ & $-0.153 * *$ \\
\hline & {$[0.057]$} & {$[0.075]$} & {$[0.070]$} & {$[0.070]$} \\
\hline \multirow[t]{2}{*}{ L.Comp2 } & 0.040 & 0.106 & 0.104 & -0.043 \\
\hline & [0.181] & {$[0.217]$} & [0.192] & {$[0.225]$} \\
\hline \multirow[t]{2}{*}{ L.Comp3 } & 0.356 & 0.513 & 0.175 & 0.265 \\
\hline & {$[0.422]$} & {$[0.562]$} & {$[0.446]$} & [0.593] \\
\hline \multirow{2}{*}{ L.Comp1*Discl_Precl } & -0.215 & 0.521 & 0.271 & -0.375 \\
\hline & {$[0.297]$} & {$[0.330]$} & {$[0.423]$} & {$[0.458]$} \\
\hline \multirow[t]{2}{*}{ L.Comp2*Discl_Precl } & -0.869 & -1.011 & -0.297 & 1.726 \\
\hline & [1.087] & [1.308] & {$[1.211]$} & [1.040] \\
\hline \multirow[t]{2}{*}{ L.comp3*Discl_Precl } & 0.719 & 0.431 & 1.756 & -0.597 \\
\hline & [1.937] & [1.885] & [1.970] & [2.386] \\
\hline \multirow[t]{2}{*}{ TotalProduct } & $-0.046^{*}$ & $-0.054 * *$ & $-0.058 * *$ & $-0.059 * *$ \\
\hline & {$[0.027]$} & {$[0.025]$} & {$[0.027]$} & {$[0.028]$} \\
\hline \multirow[t]{2}{*}{ Leverage } & $1.254 * * *$ & $1.417 * *$ & $1.528 * *$ & $1.402 * *$ \\
\hline & [0.417] & {$[0.558]$} & {$[0.583]$} & {$[0.626]$} \\
\hline \multirow[t]{2}{*}{ FirmAge } & 0.078 & $0.084^{*}$ & 0.078 & 0.036 \\
\hline & {$[0.047]$} & [0.049] & {$[0.051]$} & {$[0.057]$} \\
\hline \multirow[t]{2}{*}{ Loss } & 0.208 & 0.350 & 0.069 & 0.308 \\
\hline & [0.649] & [0.813] & {$[0.763]$} & [0.728] \\
\hline \multirow[t]{2}{*}{ LogFirmSize } & -0.099 & -0.234 & -0.219 & -0.207 \\
\hline & {$[0.204]$} & [0.181] & {$[0.226]$} & {$[0.228]$} \\
\hline \multirow[t]{2}{*}{ Accruals } & 0.218 & -1.476 & 1.469 & 0.540 \\
\hline & [1.189] & [1.503] & [2.638] & [2.338] \\
\hline \multirow[t]{2}{*}{ Constant } & $4.902 * * *$ & $5.387 * *$ & $4.095 * *$ & $5.898 * * *$ \\
\hline & [1.667] & [2.463] & [1.901] & [1.850] \\
\hline Year Controls & YES & YES & YES & YES \\
\hline Observations & 248 & 245 & 231 & 231 \\
\hline R-squared & 0.240 & 0.242 & 0.200 & 0.194 \\
\hline
\end{tabular}

This table presents examines the effects of lagged preclinical-disclosure index and corporate governance on firm performance in a multivariate regression. Robust standard errors are presented in parentheses. All variables are defined in Appendix B.***,**, and $*$ denote statistical significance at the $1 \%, 5 \%$, and $10 \%$ level, respectively. 
Table 11 The effect of lagged technical-disclosure index and corporate governance on firm performance

\begin{tabular}{|c|c|c|c|c|}
\hline VARIABLES & $\begin{array}{l}(1) \\
\text { TQ }\end{array}$ & $\begin{array}{c}(2) \\
T Q(t+1)\end{array}$ & $\begin{array}{c}(3) \\
T Q(t+2)\end{array}$ & $\begin{array}{c}(4) \\
\mathrm{TQ}(\mathrm{t}+3)\end{array}$ \\
\hline Tech_Discl & $\begin{array}{c}25.466^{* *} \\
{[9.946]}\end{array}$ & $\begin{array}{l}31.191 * * \\
{[11.787]}\end{array}$ & $\begin{array}{l}22.225^{*} \\
{[12.142]}\end{array}$ & $\begin{array}{c}9.045 \\
{[11.442]}\end{array}$ \\
\hline L.Comp1 & $\begin{array}{l}-0.101 \\
{[0.115]}\end{array}$ & $\begin{array}{c}0.038 \\
{[0.143]}\end{array}$ & $\begin{array}{c}-0.069 \\
{[0.131]}\end{array}$ & $\begin{array}{c}-0.049 \\
{[0.109]}\end{array}$ \\
\hline L.Comp2 & $\begin{array}{c}0.621^{* *} \\
{[0.245]}\end{array}$ & $\begin{array}{c}0.848^{* * *} \\
{[0.315]}\end{array}$ & $\begin{array}{c}0.823^{* * * *} \\
{[0.305]}\end{array}$ & $\begin{array}{c}0.246 \\
{[0.283]}\end{array}$ \\
\hline L.Comp3 & $\begin{array}{c}-0.203 \\
{[0.897]}\end{array}$ & $\begin{array}{c}0.799 \\
{[0.941]}\end{array}$ & $\begin{array}{c}0.733 \\
{[1.045]}\end{array}$ & $\begin{array}{c}0.005 \\
{[0.818]}\end{array}$ \\
\hline L.Comp1*Tech_Discl & $\begin{array}{c}-0.081 \\
{[0.479]}\end{array}$ & $\begin{array}{c}-0.600 \\
{[0.532]}\end{array}$ & $\begin{array}{c}-0.248 \\
{[0.455]}\end{array}$ & $\begin{array}{c}-0.445 \\
{[0.365]}\end{array}$ \\
\hline L.Comp2*Tech_Discl & $\begin{array}{c}-2.877 * * * \\
{[1.056]}\end{array}$ & $\begin{array}{c}-3.670 * * * \\
{[1.256]}\end{array}$ & $\begin{array}{c}-3.288 * * \\
{[1.400]}\end{array}$ & $\begin{array}{c}-0.550 \\
{[1.423]}\end{array}$ \\
\hline L.Comp3*Tech_Discl & $\begin{array}{c}2.796 \\
{[2.759]}\end{array}$ & $\begin{array}{c}-1.362 \\
{[2.934]}\end{array}$ & $\begin{array}{l}-1.221 \\
{[3.225]}\end{array}$ & $\begin{array}{c}1.034 \\
{[2.741]}\end{array}$ \\
\hline TotalProduct & $\begin{array}{c}-0.075 * * \\
{[0.034]}\end{array}$ & $\begin{array}{c}-0.080 * * \\
{[0.032]}\end{array}$ & $\begin{array}{c}-0.098 * * * \\
{[0.035]}\end{array}$ & $\begin{array}{c}-0.082 * * \\
{[0.039]}\end{array}$ \\
\hline Leverage & $\begin{array}{c}1.204 * * * \\
{[0.384]}\end{array}$ & $\begin{array}{l}1.135^{* *} \\
{[0.531]}\end{array}$ & $\begin{array}{l}1.307 * * \\
{[0.498]}\end{array}$ & $\begin{array}{c}1.196 * * \\
{[0.553]}\end{array}$ \\
\hline FirmAge & $\begin{array}{l}0.079 * \\
{[0.042]}\end{array}$ & $\begin{array}{c}0.083^{*} \\
{[0.044]}\end{array}$ & $\begin{array}{c}0.065 \\
{[0.048]}\end{array}$ & $\begin{array}{c}0.041 \\
{[0.051]}\end{array}$ \\
\hline Loss & $\begin{array}{c}0.245 \\
{[0.521]}\end{array}$ & $\begin{array}{c}0.288 \\
{[0.680]}\end{array}$ & $\begin{array}{l}-0.144 \\
{[0.627]}\end{array}$ & $\begin{array}{c}0.129 \\
{[0.712]}\end{array}$ \\
\hline LogFirmSize & $\begin{array}{c}-0.236 \\
{[0.168]}\end{array}$ & $\begin{array}{c}-0.303 * * \\
{[0.146]}\end{array}$ & $\begin{array}{c}-0.217 \\
{[0.206]}\end{array}$ & $\begin{array}{c}-0.178 \\
{[0.209]}\end{array}$ \\
\hline Accruals & $\begin{array}{c}-0.558 \\
{[1.191]}\end{array}$ & $\begin{array}{c}-0.902 \\
{[1.522]}\end{array}$ & $\begin{array}{c}1.667 \\
{[2.452]}\end{array}$ & $\begin{array}{c}0.942 \\
{[2.159]}\end{array}$ \\
\hline Constant & $\begin{array}{c}1.568 \\
{[2.430]}\end{array}$ & $\begin{array}{c}-0.519 \\
{[3.027]}\end{array}$ & $\begin{array}{l}-0.120 \\
{[2.828]}\end{array}$ & $\begin{array}{c}2.399 \\
{[2.557]}\end{array}$ \\
\hline Year Controls & YES & YES & YES & YES \\
\hline Observations & 252 & 249 & 235 & 235 \\
\hline R-squared & 0.252 & 0.273 & 0.235 & 0.177 \\
\hline
\end{tabular}

This table presents examines the effects of lagged technical-disclosure index and corporate governance on firm performance in a multivariate regression. Robust standard errors are presented in parentheses. All variables are defined in Appendix B.***,**, and $*$ denote statistical significance at the $1 \%, 5 \%$, and $10 \%$ level, respectively. 